\title{
Metis Constitutional Rights in Section 35(1)
}

\section{CATHERINE Bell}

In this article, the author explores the need for $a$ theory of Aboriginal rights broad enough to include all of the Aboriginal peoples of Canada. She examines recent developments in judicial recognition of the constitutional rights of the Metis people since their inclusion in s. 35(I) of the Constitution Act, 1982 and applies the fiduciary principle to dealings between the federal government and the Metis. The author also argues that the Metis' inclusion in s. 35(I) suggests that their rights are inherent, sui generis rights.

However, the author is concerned about decisions such as R. v. Van der Peet, which may limit Aboriginal s. 35 rights to the protection of precontact activities that were, and continue to be, central to Aboriginal culture. The author argues that using European contact as a blanket cut-off point for defining rights of all Aboriginal peoples could threaten the rights of the Metis, whose culture is a blend of European and Aboriginal elements. A more appropriate date is suggested for measuring the existence of historical Metis rights, namely the date of actual imposition or negotiation of colonial law or government.
L'auteure traite de la nécessité de disposer d'une théorie des droits des autochtones suffisamment large pour inclure tous les peuples autochtones du Canada. Elle examine lévolution récente de la reconnaissance judiciaire des droits constitutionnels des Métis depuis leur inclusion au par. 35(1) de la Loi constitutionnelle de 1982, et applique le principe de fiduciaire aux relations entre le gouvernement fédéral et les Métis. Selon l'auteure, cette inclusion suggérerait que les droits des Métis sont des droits sui generis.

L'auteure se dit toutefois préoccupée par les décisions rendues dans $\mathbf{R}$. c. Van der Peet, notamment, susceptibles de restreindre la garantie des droits visés au par. 35(1) aux activités préeuropéennes qui ont toujours fait partie intégrante de la culture autochtone. L'auteure affirme que le fait d'utiliser le contact avec les Européens comme critère global de définition des droits de tous les peuples autochtones pourrait menacer les droit des Métis, dont la culture est un mélange d'éléments européens et autochtones. Elle propose un critère qui permettrait mieux de déterminer l'existence des droits historiques des Métis - la date réelle d'imposition ou de négociation du droit ou du régime colonial.

\section{TABLE OF CONTENTS}

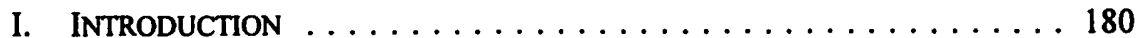

II. INHERENT, SUI GENERIS RIGHTS

OF CONTEMPORARY PEOPLES . . . . . . . . . . . . . . 183

III. EQUALITY, EQUIVALENCY AND DIFFERENCE $\ldots \ldots \ldots \ldots \ldots 191$

IV. THE FEDERAL-METIS RELATIONSHIP $\ldots \ldots \ldots \ldots \ldots \ldots \ldots 196$

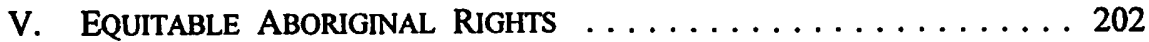

VI. INHERENT METIS RIGHTS $\ldots \ldots \ldots \ldots \ldots \ldots \ldots \ldots \ldots \ldots$

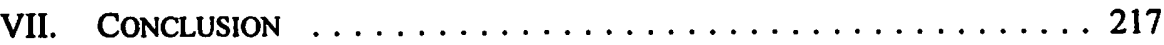

\section{INTRODUCTION}

Prior and subsequent to the explicit constitutional recognition of Metis as Aboriginal, contemporary jurisprudence on the rights of Metis people has focused on their ability to prove Aboriginal title, the continued survival and significance of cultural traits

Associate Professor of Law, Faculty of Law, University of Alberta. This article was funded in part by the Social Sciences Humanities Research Council. I am grateful to Dale Gibson for his helpful comments on earlier drafts of this article. 
emphasized in judicial constructions of "traditional Indian life," and the Crown's intent to extinguish potential rights founded on occupation and lifestyle.' These issues were, and remain, dominant because they are considered crucial to Metis economic and cultural survival and because a substantial amount of Metis rights litigation arises as a result of charges being laid against Metis people asserting rights to hunt and fish. However, conceptual barriers to judicial recognition of Metis rights inevitably arise because of the assumption that Aboriginal constitutional rights recognized and affirmed in s. 35(1) of the Constitution Act, 1982 can only be enjoyed by those peoples who can prove an exclusive relationship to land sufficient to support a claim to Aboriginal title. ${ }^{2}$ As a result of recent rulings by the Supreme Court of Canada, these barriers are no longer insurmountable.

The scope of potential rights and the categories of peoples entitled to exercise them have also been expanded by the introduction of the concept of fiduciary obligation into legal and political analysis of government actions affecting Aboriginal peoples. As the fiduciary principle acquires greater significance in judicial analysis, government obligations to Aboriginal peoples, formerly characterized as political or moral in nature, are being elevated to enforceable, equitable obligations which in turn may generate justiciable, equitable Aboriginal rights. Emphasis on the fiduciary obligations of the British and Canadian governments in their dealings with Aboriginal peoples has also increased the significance of dishonourable and harmful government conduct in the legal analysis of alleged extinguishment. For the Metis, this is another favourable development as twentieth-century federal policy has for the most part denied the existence of Metis Aboriginal rights and, in the alternative, has maintained that whatever rights they may have had were effectively terminated through the scrip distribution system. The application of fiduciary law to the federal-Metis relationship could mean that defects in the implementation of the scrip distribution system nullify extinguishment or generate equitable Metis constitutional rights. This issue is currently the subject of litigation and negotiation. ${ }^{3}$

Despite these developments, Metis may continue to experience difficulty asserting the existence of inherent Metis constitutional rights because of the revival of judicial

1 The phrases "traditional Indian life" and "Indian lifestyles" are used by the author to describe the vision of pre-contact lifestyle, customs, traditions and practices of the ancestors of contemporary First Nations currently adopted by the Supreme Court of Canada. The term "Indian" is also used to distinguish Indian peoples from Metis and Inuit peoples also recognized as distinct Aboriginal Peoples in s. 35(2) of the Constitution Act, 1982, being Schedule B to the Canada Act 1982 (U.K.), 1982, c. 11.

2 See e.g. T. Flanagan, "The Case Against Metis Aboriginal Rights" (1983) 9 Canadian Public Policy 314. In a later article he expands these views and suggests Metis may have derivative title subordinate to Indian title ("The History of Metis Aboriginal Rights: Politics, Principle and Policy" (1996) 5 Can. J. Law \& Soc. 71). See also R. v. Blais, [1997] 3 C.N.L.R. 109 (Man. Prov. Ct.). Dumont v. Canada (A.G.) and Manitoba (A.G.), sub nom. Manitoba Metis Federation v. Canada (A.G.), [1987] 2 C.N.L.R. 85 (Man. Q.B.), rev'd [1988] 3 C.N.L.R. 39 (Man. C.A.), rev'd [1990] 2 C.N.L.R. 19 (S.C.C.) [hereinafter Dumont]. Litigation is now proceeding on numerous issues arising from the allocation of lands to Metis residents of Manitoba under s. 31 of the Maniloba Act 1870 , S.C. 1870, c. 3 including breach of fiduciary obligation and the constitutional validity of methods adopted to implement ss. 31 and 32 . 
restraint in Aboriginal rights analysis. Influenced by the potential social, political and economic impact of liberal constructions of Aboriginal constitutional rights, the current Supreme Court may have signalled a retreat to earlier patterns of judicial reasoning which emerged in the context of Aboriginal claims to proprietary interests. Despite the expansion of Aboriginal rights beyond the realm of property law, the elevation of Aboriginal rights to constitutional rights, and the generous and prospective approach to definition that their constitutional status demands, the present Supreme Court has characterized Aboriginal rights in a way that severely limits the significance of their constitutional and contemporary nature. Of particular concern is the recent ruling in $R$. v. Van der Peet, which limits s. 35 Aboriginal rights to the protected exercise of precontact Indian activities that were, and continue to be, a central and defining feature of Aboriginal culture. ${ }^{4}$ The emergence of this judicial formula suggests that a uniform standard cannot be applied to Indians, Inuit and Metis if the inclusion of Metis as distinct Aboriginal peoples in s. 35 of the Constitution Act, 1982 is to be given substantive meaning.

The purpose of this article is to raise some of the special issues faced by Metis people in achieving judicial recognition of their constitutional rights in light of the above developments. In particular, it focuses on the origins of Metis rights and explores the need for a theory of rights which is comprehensive enough to include rights derived from Indian or Inuit lineage and lifestyle and unique Metis rights which inhere to the Metis Nation as a distinct Aboriginal people. ${ }^{5}$ The article is influenced by the belief that it is impossible and undesirable to dissect Metis institutions that emerged as a result of cultural blending into functionally distinct Indian, Inuit and European influences. It also argues that the date of imposition, or negotiation, of colonial law and government is the appropriate date to measure the existence of historical Metis institutions upon which a second sui generis order of Metis rights can be based. Underlying the argument for a distinct order of Metis rights is a concern that the trend in domestic law to focus on "Aboriginality," without equal emphasis on distinct culture, political organization and national affiliation, fosters judicial assimilation of contemporary rights-bearing Metis collectivities with Indian, Inuit and European ancestral populations. ${ }^{6}$ In circumstances where mixed ancestry people identify

R v. Van der Peet, [1996] 4 C.N.L.R. 177 (S.C.C.) [hereinafter Van der Peet].

For the purpose of this article, the author is adopting the theory of Metis identification endorsed by the Royal Commission on Aboriginal Peoples. The term Metis Nation is used to distinguish those who are descendants of the Red River Metis and identify with the contemporary Metis Nation. The phrase "other Metis" is used to describe self-identifying Metis populations who are not connected to the Metis Nation or choose not to identify with the Metis National Council which represents descendants of the Metis Nation on a national level. See "Metis Perspectives" in Report of the Royal Commission on Aboriginal Peoples, vol. 4, c. 5 (Ottawa: Canada Communication Group, 1997) (Co-Chairs R. Dussault \& G. Erasmus) at 199-208 [hereinafter R.C.A.P.]. For a discussion of the complexity of this issue see C. Bell, "Who are the Metis People in s. 35(2)?" (1991) 29 Alta. L. Rev. 351 [hereinafter "Metis People"] and P. Chartrand, "Terms of Division: Problems of 'Outside-Naming' For Aboriginal People in Canada" (1991) 2 Journal of Indigenous Studies 1.

- In Van der Peet, supra note 4, emphasis is placed on the Aboriginal nature and the term "Aboriginality" is used to identify those aspects of Aboriginal culture that historically distinguished Aboriginal people from non-Aboriginal people. It is used in the same way throughout the article. 
themselves as "non-treaty" or "non-status" and distinctions based on different cultural institutions are not appropriate, this outcome may not be objectionable. However, for those historical and contemporary people who identify with a distinct Metis culture, judicial assimilation is simply a different manifestation of an old federal policy of nonrecognition.

To avoid this result and give substantive meaning to the recognition of Metis as a distinct and contemporary people, this article argues that Metis constitutional rights can only be understood by looking to various original sources of rights and law which shape the Canadian Aboriginal rights regime. Although the author recognizes the importance of including Aboriginal legal institutions and international law in the collective and diverse streams of law that shape contemporary domestic laws, this article is limited in its focus to arguments sourced in the non-Aboriginal domestic legal system. In particular, the following sources of Metis rights are considered:

(a) s. 35 of the Constitution Act, 1982, which recognizes and affirms the existence of the Metis as an Aboriginal people and thereby confirms the fiduciary obligation of the Crown to Aboriginal people;

(b) Aboriginal ancestry and the continuance of practices integral to a judicially constructed traditional Indian lifestyle;

(c) Metis culture, Metis political organization and the continuance of practices integral to a distinct Metis way of life at the date of effective colonization; and

(d) the human rights of peoples.

\section{Inherent, SUI Generis Rights of Contemporary Peoples}

Section 35(2) of the Constitution Act, 1982 identifies the Aboriginal peoples as including the Indian, Inuit and Metis peoples. The inclusion of Metis as a distinct Aboriginal people complements the increasing legal relevance of social and political institutions of self-identifying contemporary and historic Aboriginal peoples in the definition of their rights. Also pivotal in the recognition of distinct constitutional and cultural entities is the political atmosphere within which S. 35 was negotiated. ${ }^{7}$ Growing activity at the United Nations aimed at ending colonial domination resulted in increased international pressure on nation states to recognize and protect the human rights of colonized peoples. Within Canada, Aboriginal peoples were asserting the right to self-identify and to be self-determining in the negotiation of their political relationship with Canada. Legal action was also taken to ensure that amendments to the Canadian Constitution would not proceed without some protection of the Aboriginal and treaty rights of colonized peoples. ${ }^{8}$ Although federal and provincial governments

7 R. v. Sparrow, [1990] I S.C.R. 1075 at 1105 [hereinafter Sparrow] states that the political history leading up to the inclusion of s. 35 in the Constitution Act, 1982 is relevant to its interpretation. $R$ v. Secretary of State (U.K.), [1982] 2 All E.R. 118 (C.A.). 
rejected the notion of Aboriginal sovereignty and self-determination, they were prepared to acknowledge the existence of unique cultural rights arising from original indigenous occupation and social organization. The exact nature, scope and content of these rights was left open for future negotiation and litigation. Inclusion of the Metis and Inuit as distinct "peoples" in the constitution, and independent representation of these peoples at subsequent constitutional conferences ensured that Aboriginal rights, whatever they were, would be attributable to Aboriginal people of the present, not simply of the past.' However, these rights were qualified by the inclusion of the term "existing," which effectively reduced the scope of contemporary constitutional Aboriginal rights to those which survived the exercise of federal powers of termination prior to 17 April $1982-$ the date Aboriginal rights were elevated from common law to constitutional status.

Inclusion in s. 35 also suggests that Metis rights are inherent constitutional rights. Although the concept of inherent rights is commonly used in legal and political consideration of s. 35(1), it carries with it different meanings for the various parties affected by its use. For many Aboriginal people, "inherent" means sourced in the creator. For some politicians it means Aboriginal rights are no longer dependant on legislative acts of recognition because they are now rooted in the Canadian Constitution. In judicial discourse, the concept is commonly understood to reflect the fact that prior to the assertion of British sovereignty, Canada was occupied by Aboriginal societies. As a result of this varied understanding of inherent rights, judicial emphasis has been placed on the word "aboriginal" in s. 35. As a corollary of this emphasis, emerging theories on Metis rights have drawn on genealogical tracing to precontact Indian and Inuit society in the quest for the origins of contemporary Metis constitutional rights. However, if the concept of inherent rights is combined with the sui generis nature of those rights, more comprehensive theories on the origin of Metis rights emerge.

The characterization of Aboriginal rights as sui generis, or unique, originally provided Canadian courts the opportunity to avoid principles of international law manipulated to deny the existence of enforceable treaty obligations and principles of Anglo-Canadian property law that unnecessarily restricted the quality and scope of rights arising from Aboriginal title. ${ }^{10}$ As a tool of judicial interpretation, it has been invoked to distinguish precedent and to legitimize the consideration of new sources of law to ascertain the nature and content of contemporary Aboriginal rights. The combined effect of the characterization of Aboriginal constitutional rights as inherent and sui generis is to support theories of rights which arise not only from the ancestral Indian or Inuit character of Aboriginal rights, but also the legal origins of the Aboriginal rights regime. A consideration of both ancestral origins and legal origins takes comprehensive rights analysis beyond rights sourced in racial descent to rights

In his dissenting opinion in Dumont, supra note 3 at 48 , O'Sullivan J. supported the conclusion that the term "people" is to be given contemporary and historical significance and that "the existence of Metis people is asserted in the Constitution as of the present, not simply as of the past." See also D. Gibson, "General Sources of Metis Rights," Appendix 5A to R.C.A.P., supra note 5 at 271.

to Simon v. R, [1986] 1 C.N.L.R. 153 at $168-69$ (S.C.C.) [hereinafter Simon]; Guerin v. $R$, [1984] 2 S.C.R. 335 [hereinafter Guerin]. 
sourced in essential attributes of "peoplehood or nationhood." approach, a proper interpretation of rights in s. 35 is one which places equal emphasis on the words "aboriginal" and "peoples" in assessing the origin, scope and content of Aboriginal rights.

Rights arising from peoplehood are uncertain because the word "peoples" is not defined in Canadian constitutional law and minimal domestic judicial opinion has been rendered on this point. However, it is a term which was used frequently in international political discourse at the time s. 35 was negotiated to distinguish colonized indigenous populations from nation states and ethnic minority immigrant populations within those states. The identification as colonized peoples carried with it potential recognition of land rights sourced in original occupation of colonized territories as well as human rights sourced in existence as a people. The main distinction drawn between the human rights of ethnic minority populations and indigenous peoples was the existence of political rights arising from the injustices perpetrated by the project of colonization. The most fundamental of these political rights are the rights to self-determine membership in, and governmental relations with, nation states, or alternatively, the right to secede. $^{12}$ Other human rights attributed to self-determining peoples then and now include: the right to economic, cultural and social development; the right to "maintain and strengthen their distinct identities and characteristics"; the right to "maintain and develop their distinctive spiritual and material relationship with the lands" and the right to restitution for unlawful termination of these rights. ${ }^{13}$

Both the political discourse around s. 35 and the domestication of Aboriginal rights through their incorporation into the Canadian Constitution suggest that the international understanding of peoplehood will be modified if it is used as a domestic tool for legal interpretation. Although Aboriginal peoples assert their rights in international law, the federal and provincial governments have historically denied the sovereign and contemporary self-determining status of Indian, Inuit and Metis peoples. Sparrow's recognition of the relevance of political context and Aboriginal perspectives in interpreting s. 35 suggests both of these factors must be considered in reaching a domestic compromise that accommodates Aboriginal and state goals. ${ }^{14}$ Pragmatism may also require such modification to meet the needs of peoples who are no longer

The use of the terms "nation" and "people" is discussed later in this article. They are not used here in the same sense as nation state. The term "peoplehood" is used to identify collective attributes such as "social cohesiveness, collective self-consciousness, cultural distinctiveness and effective political organization." R.C.A.P., supra note 5 at 206.

See The International Covenant on Economic, Social and Cultural Rights, 16 December 1966, 993 U.N.T.S. 3 (entered into force 3 January 1976) arts. 1 and 2; and The International Covenant on Civil and Political Rights, 19 December 1966, 999 U.N.T.S. 171 (entered into force 23 March 1976) art. 27 in The International Bill of Human Rights (New York: United Nations, 1978) and the proposed Draft Integrational Declaration on the Right of Indigenous Peoples, UN Document E/CN.41 Sub2/1993/29, reproduced in [1994] 1 C.N.L.R. at 40 [hereinafter Draft Declaration]. For a discussion of the distinction between nation states, peoples and populations in international law see S. Venne, International Law Regarding Indigenous Peoples (LL.M. Thesis, Faculty of Law, University of Alberta, 1997) [unpublished] c. 3. 
economically self-sustaining and wish to enjoy the civil, political and economic rights of Canadian citizenship.

A compromise endorsed by numerous legal scholars as well as the Royal Commission on Aboriginal Peoples (R.C.A.P.) is an understanding of peoplehood that draws on social science criteria of nationhood. This concept of nationhood is one that emphasizes "a psychological bond joining a people and differentiating them from others, an aversion to being ruled by others, common ideology, common institutions and customs, and a sense of homogeneity."15 It may involve some qualified form of self-determination within the context of Canadian federalism, but such a right would arguably fall short of a right to secede. ${ }^{16}$ The history of the Charlottetown Accord suggests that such a compromise would be more acceptable to Metis, Inuit and Nontreaty Indian peoples than to Treaty Nations. ${ }^{17}$ However, it should be noted that the exclusion of certain international norms from the constitutional interpretive framework does not mean Aboriginal peoples were not historically sovereign in status or that they do not have a right to self-determination. Nevertheless, modification does reinforce the position that the recognition of Aboriginal sovereignty and the affirmation of the right of Aboriginal peoples to self-determine outside of the structure of the nation state is not a subject that can be adjudicated within the confines of the Canadian legal and constitutional regime. For this reason, it may be necessary for Aboriginal peoples to continue to lobby domestically and abroad for an international court or some other unique body to adjudicate matters arising from the international Aboriginal-federal relationship.

When incorporated into the interpretation of the word "peoples" in s. 35, this domestic compromise is still an independent source of rights distinct from Indian or Inuit ancestry. It is peoplehood, not lineage, that is the source of rights to selfgovernment and cultural institutions essential to the self-identity and preservation of distinct Aboriginal societies. Therefore, as the Metis Nation emerged as (and remains) a distinct Aboriginal people, their peoplehood, as well as their Aboriginal ancestry, are properly considered sources of constitutional rights. ${ }^{18}$ Arguably emphasis on Aboriginality and peoplehood requires both identification of institutions which, if they did not exist, could "fundamentally alter" distinct Metis culture from what it was and

"Metis People," supra note 5 at 364.

This interpretation is supported by the inclusion of Aboriginal peoples in the Canadian constitutional regime and provisions of the Draft Declaration, supra note 12, that restrict the rights of peoples to establish nation states.

See e.g. the position of the Metis Nation reflected in the Proposed Metis Nation Accord which was to be negotiated pursuant to the relevant promises in the Charlottetown Accord in RC.A.P., supra note 5 at 376. The Charlottetown Accord was signed 28 August 1992 but was not implemented. References in this article are to the Draft Legal Text published on 9 October 1992.

R.C.A.P., supra note 5 at 207 suggests that other peoples that identify as Metis may be sufficiently organized to be identified as distinct nations from the Metis Nation. An example are the Labrador Metis who "exhibit] the historical rootedness, social cohesiveness and cultural self-consciousness that are essential to nationhood." Other Metis may be "emerging nations" which had not yet reached nationhood at the time s. 35 was negotiated. For the purpose of negotiation, they suggest the only "relevant question is whether the negotiating organization has a mandate to negotiate on behalf of those it purports to represent." 
those institutions that Metis have in common with their pre-contact Indian or Inuit ancestors. ${ }^{19}$ This understanding of the duality of Metis constitutional rights has not been expressly articulated by Canadian courts, but must be considered in the context of Metis rights if substantive meaning is to be given to their Aboriginal constitutional rights as Aboriginals and autonomous peoples.

Existence as a historic and contemporary people with inherent and sui generis rights also raises questions about the identification of original laws that governed AboriginalCrown relations. Disagreement arises on whether historical Aboriginal political organization was sufficient in the eyes of European colonizers to raise the law of nations as a framework for understanding the original legal relationship. Indeed, this framework has been rejected in Canadian judicial analysis of Indian rights for various reasons, including: purported Indian acknowledgment of British sovereignty through treaty making; the inability of Canadian courts to challenge the sovereign status of the Crown and the application of Canadian law to Aboriginal peoples in Canada; and the inconsistent patterns of historical relations between the Crown and Aboriginal peoples. Consequently, the judicial tendency is to focus on British colonial origins of domestic law when complex Aboriginal rights questions cannot be answered using principles and precedents set by Canadian courts. The legitimacy of relying on British colonial law to the exclusion of indigenous and other legal regimes is rarely addressed. Rather it is assumed legitimate as part of the Anglo-Canadian manifestation of the Western process of legal reasoning. Central in Canadian legal reasoning is the doctrine of stare decisis which assumes that lower courts must follow like decisions of higher courts within the same judicial hierarchy to the extent that those decisions are similar. Analysis of contemporary legal issues begins by looking up and to the past. If a helpful principle cannot be found in similar decisions within the Canadian legal hierarchy, the next best place to look is to England - the country from which the Canadian legal and political system has predominantly evolved. Old rules are then manipulated to fit new situations in order to escape "the folly of perpetuating to eternity, principles unsuited to modern circumstances."20

Judicial consideration of British colonial origins is illustrated in the Adams and Côté decisions. ${ }^{21}$ At issue in both cases was the survival of Aboriginal rights in Quebec because of the uncertain status of these rights in French colonial law and the continuation of French legal systems after the transition to British sovereignty. Adopting contemporary constitutional law and British colonial law as appropriate frameworks for analysis, the Supreme Court acknowledged that contemporary Aboriginal constitutional rights may be shaped by a unique body of British imperial law applicable to all Aboriginal peoples, including Aboriginal peoples in Quebec. This law, known as the "doctrine of aboriginal rights, like other doctrines of colonial law" may

19 Lamer C.J.C. uses this concept in Van der Peet, supra note 4 at 204 to identify practices, traditions and customs integral to an Aboriginal culture.

Dickson J. (as he then was), "The Role and Function of Judges" (1980) 14 L. Soc. Gaz. 138 at 182. 
have applied to Aboriginal people in a new colony whenever a colony was acquired. ${ }^{22}$ If this is the case, while the British regime continued French colonial law within Quebec it may, as a necessary incident of British sovereignty, have not continued French colonial law governing the relations between the French Crown and Aboriginal peoples. Although this reasoning was not ultimately adopted in the resolution of the case, it is clear that the Supreme Court is willing to expand its vision of rights in difficult cases. Lamer C.J.C. avoided choosing between French and British colonial law by looking to the purpose of s. 35(1) and determining whether the right to fish for food had been extinguished. Noting that the purpose of s. 35(1) is to preserve the "integral and defining features of distinctive Aboriginal societies," he invoked principles of contemporary Canadian constitutional law which, in furtherance of this purpose, require a clear and plain intention by the colonizer to extinguish specific Aboriginal rights. Lack of "recognition and approval of European colonizers" is not enough to terminate Aboriginal rights. ${ }^{23}$ If it was, Lamer C.J.C. cautions, s. 35 would merely perpetuate "historical injustice suffered by Aboriginal peoples at the hands of colonizers who failed to respect the distinctive cultures of pre-existing Aboriginal societies." 24

If the Supreme Court wishes to accommodate the equally complex historical situation of the Metis Nation, it could focus on the "injustice suffered" by Metis at the hands of "colonizers who failed to respect [Metis] distinctive cultures." 25 This could result in looking to British colonial law, Indian social organization and constitutional law to ascertain the origin of their rights. If emphasis is given to the "distinctive culture" or peoplehood dimension of their rights, distinct Metis cultural institutions and Metis law also become relevant. The proper framework becomes one that examines the injustices arising from "the meeting of two vastly dissimilar legal cultures" and community institutions. ${ }^{26}$ However, the injustices perpetrated against the Metis and the impact of the assertion of sovereignty on their distinct laws and institutions could be lost if judges identify the British as the only relevant legal colonizers in the assessment of Aboriginal rights. Depending on the date selected for measuring the assertion of English sovereignty, Metis may not have emerged beforehand as distinct peoples. Therefore, it may be difficult to argue for the existence of Metis peoplehood rights independent of rights arising from their Indian lineage. Such an approach would minimize the relevance of the constitutional recognition of Metis as distinct peoples. As the Supreme Court has stated that it is "entirely contrary to the spirit and intent of s. 35(1) to define Aboriginal rights in such a fashion so as to preclude in practice any successful claim for the existence of such a right," and the reasons underlying the inclusion of Metis rights in s. 35 are "quite distinct from those of other Aboriginal peoples in Canada," judges may be reluctant to adopt an approach which promotes such a result. ${ }^{27}$

B. Slattery, "Understanding Aboriginal Rights" (1987) 66 Can. Bar. Rev. 727 at 737.

Cóté, supra note 21 at 48.

Ibid. at 48-49.

lbid.

M. Walters, "British Imperial Constitutional Law and Aboriginal Rights: A Comment on Delgamuukw v. British Columbia" (1992) 17 Queen's L.J. 350. This notion is acknowledged by Lamer C.J.C. in Van der Peet, supra note 4 at 199 but is not given substantive meaning. See J. Borrows, "The Trickster: Integral to a Distinctive Culture" (1997) 8 Constitutional Forum 27. Supra note 4 at 205 and 207. 
In developing a process for the definition of Metis rights which is inclusive of their peoplehood status, the court may have to reconsider the legal relevance of distinguishing between the assertion of sovereignty and the actual historical process of colonization. In the context of Indian and Inuit rights these concepts have been used loosely and interchangeably to identify the date for measuring the original Aboriginal institutions which the Crown had the power to terminate at common law, and which are now protected in s. 35. As Indians and Inuit existed as distinct peoples at the assertion of sovereignty vis-à-vis other European nation states and at the time of actual imposition of foreign laws and customs on their communities, the failure to draw the distinction between sovereignty and colonization seems insignificant. However, in the context of Metis rights it is important to draw distinctions. The assertion of sovereignty emerged as a pivotal date to determine rights arising from prior occupation from which, until recently, it was thought all Aboriginal rights must flow. ${ }^{28}$ In some cases it is identified through the existence of charters, proclamations, legislative assertion of jurisdiction or treaty-making with other European nations. In others, it is identified as the time of European settlement and the imposition of English law on a particular Aboriginal people. Other opinions point to the cumulative effect of some or all of these events. Although general proclamations, declarations and other imperial actions are relevant in ascertaining England's rights vis-à-vis other Europeans, they are irrelevant in ascertaining their rights vis-à-vis particular Aboriginal peoples in Canada. ${ }^{29}$ After the proclamation of English sovereignty many peoples lived unaffected by English law and customs. It is only through the historical process of colonization which occurred before, during and after assertions of sovereignty that Aboriginal societies became fundamentally altered.

Colonization refers to an actual historic process which occurred before, during and after England asserted sovereignty over various areas in Canada. It refers to the actual dispossession of land, the imposition of one legal system over another, the amalgamation of autonomous political entities and gradual assimilation of the colonized. It is the continual process of "bringing into subjection or subjugation" people who are living in a territory being colonized by Europeans. ${ }^{30}$ British colonial law governing this process, and the actual relations between the colonizer and the colonized are the legal basis of Aboriginal rights recognized in s. $35(1){ }^{31}$ Understood in this context, s. 35(1) does not address injustices arising from a theoretical shift in legal and political regimes that occurs as a result of the assertion of sovereignty but actual injustices suffered by "peoples" as a corollary of British sovereignty through the historical

Adams, and Côté, supra note 21, now put to rest that Aboriginal rights are limited to those rights arising from title. Per Lamer C.J.C. in Adams, at 11: "while claims to Aboriginal title fall within the conceptual framework of Aboriginal rights, Aboriginal rights do not exist solely where a claim to Aboriginal title has been made out." For further discussion see page $\mathbf{2 1 2}$ of this article. Worcester v. State of Georgia, (1832) 8 U.S. (6 Pet.) 515. See also Slattery, supra note 22. J. Stein, ed., The Random House Dictionary of the English Language (New York: Random House, 1966) at 291. The quotation is from the definition of "colonialization."

Sparrow, supra note 7 at 1103 and Slattery, supra note 22. Lamer C.J.C. seems to adopt this understanding in his emphasis on the role of the colonizer and the injustices of colonization in Côté, supra note 21 at 48-49. However, he does not appreciate the distinction between contact and colonization in his assessment of when to determine the historical origins of $\mathrm{s}$. 35 rights. 
process of colonization. Although the date of colonization varies across the country depending on the historical circumstances of colonization, British colonial law is constant in determining the effects of this process on the survival of distinct Aboriginal social and political constitutions. In spite of sovereignty proclamations and actual colonization, the British recognized that Aboriginal title and distinctive Aboriginal social institutions survived in law unless they were extinguished through defined processes or were inconsistent with the concept of sovereignty or laws that clearly and plainly extinguished them. ${ }^{32}$ The issue of selecting the date of colonization in ascertaining the historic and legal origins of Metis rights is discussed in further detail below. The point here is that a distinction should be drawn between the concepts of sovereignty and colonization in order to acquire a full appreciation of the distinct peoplehood rights recognized at common law and protected in s. 35 .

If both the concepts of sovereignty and colonization are adopted as key organizational principles for interpreting s. 35, the inclusion of Canada as colonizer is a natural extension of s. 35 analysis. Prior to its emergence as an independent nation state, the Dominion of Canada operated as the colonizing arm of British Imperial government. It assumed the rights and responsibilities of the Imperial colonizer toward Indian and Inuit peoples under s. 91(24) of the Constitution Act, 1867 and imposed British rule through negotiation, occupation and force. ${ }^{33}$ It effectively imposed this rule in Rupert's Land in 1870, after the Riel resistance and as a result of the negotiation of the Manitoba Act. ${ }^{34}$ There is no doubt that the Metis Nation had emerged as a distinct Aboriginal people by this time. It is this date, the peak of colonization, not some earlier time at which Britain may have declared or acted in accordance with an assumption of sovereignty, that is the relevant date to identify the colonizer, the colonized and the peoplehood rights of the Metis in Manitoba. Different dates may be more appropriate for other Metis such as those living in the Northwest Territories or in Labrador. It may be that other Metis did not emerge as a distinct people before the peak of colonization in their present location and that their rights are limited to those that are Indian or Inuit, rather than peoplehood, in their origins. ${ }^{35}$ This will be a question of historical fact in its application to all contemporary self-identifying peoples. $^{36}$

In summation, the inclusion of Metis in s. 35 of the Constitution suggests that their constitutional rights are inherent sui generis rights. If equal consideration is given to the characterization of these rights as sui generis, the possibility exists for a more comprehensive understanding of Metis rights that extends beyond rights derived from Indian or Inuit ancestry. The sui generis nature of these rights provides precedential

Sparrow, supra note 7 at 1103 and 1110. See also RC.A.P., supra note 5, vol. 2(1) at 186-213. (U.K.), 30 \& 31 Vict., c. 3.

S.C. 1870 , c. 3 .

See discussion, supra note 18.

Unfortunately, the recent trend in decision-making around Indian rights suggests the relevant date for identifying distinct Indian institutions will be pushed back to first contact which may pre- or post-date the assertion of English sovereignty in a given area. If applied strictly to Metis rights, selection of this date may mean even the Metis Nation does not have distinct peoplehood rights that distinguish them from the rest of Aboriginal society. 
foundation for Canadian courts to look beyond domestic law for rules to guide in the interpretation of s. 35. In its attempts to understand the significance of the inclusion of the term "peoples," Canadian courts may look to British colonial law or modified norms of international law to develop interpretive tools. Both of these sources of law, as well as the present judicial understanding of the purpose of s. 35, support using the actual pattern and effects of colonization to measure the historical origins of s. 35 rights. In order for substantive meaning to be given to the peoplehood dimensions of Metis constitutional rights, the relevant date for assessing their distinct cultural institutions may have to be pushed forward to the peak of colonization by Canada, rather than the fictional assertion of British sovereignty which, isolated from the subsequent process of colonization, may not be said to have fundamentally altered the legal and political organization of Metis peoples at that time.

\section{EQuality, EQUIVALENCY AND DIFFERENCE}

As the Constitution Act, 1982 must be read together with the Constitution Act, 1867, constitutional rights of Aboriginal peoples will also be affected by other provisions of the Canadian Constitution. ${ }^{37}$ R.C.A.P. has argued that this means the scope and exclusivity of s. 35 rights will be circumscribed by the confines of Canadian federalism. Furthermore, the appropriateness of applying Canadian law in assessing the existence and survival of Aboriginal rights will be presumed because they are clearly incorporated through constitutional recognition into the Canadian legal rights regime. ${ }^{38}$ However, within the constitutional framework there is substantial flexibility which enables the creation of various judicial formulae for the reconciliation of Aboriginal and nonAboriginal constitutional interests. Indeed, the structure itself assumes not all peoples within Canada are situated consistently in the constitutional rights regime and that various groups of peoples living within different territorial boundaries may be governed by different laws and governments. The equality principle that every Canadian citizen is "equal before and under the law and has the right to equal protection and benefit of the law" is an elastic principle which really requires that within the federal system "persons who are 'similarly situated be similarly treated' and conversely, ... persons who are "differently situated be differently treated."'39 Applied to rights protected in s. 35, these presumptions create room for the recognition of both legal rights and government institutions unique to the Aboriginal peoples of Canada. At the same time, they impose limits on the extent of those rights by including them in a constitutional regime which assumes the legitimacy of Canadian jurisdiction over all people within Canada and the existence of a paramount government that has the ability to control the lives of all people within the scope of its constitutionally recognized sphere of legislative jurisdiction. 
Inclusion in s. 35 also speaks to a range of potential constitutional relationships between Metis and other Aboriginal peoples. One possibility is to conceptualize Metis rights as independent from, but the same as, and equal in status to, the rights of other Aboriginal peoples. This approach is similar to the constitutional concept of equality adopted in the interpretation of S. 15 of the Canadian Charter of Rights and Freedoms. ${ }^{40}$ It is based in the assumption that Metis rights are justiciable legal rights derived solely from Aboriginal ancestry and a traditional Indian lifestyle. Because they are situated within the same constitutional space as other Aboriginal people, the term "aboriginal" in s. 35 is not only a defining feature of Metis people as constitutional legal entities, but also a defining feature for the nature and content of their rights. Thus, as a descriptive adjective, "aboriginal" may effectively limit Metis rights to those practices integral to Metis culture that are the same as, and are rooted in, their Aboriginal lineage. As discussed above, this notion of formal equality is problematic because it fails to give legal significance to the recognition of the Metis as a distinct people. However, it is a concept that is popular with some legal scholars and lower courts.

An example of this theory of Aboriginal formal equality is found in the reasoning of Saskatchewan Provincial Court Judge Meagher in his ruling on the existence of an unextinguished Metis Aboriginal right to fish. In a pre-trial conference, the parties agreed to focus the debate on whether the right to fish existed in the ancestors of the Metis litigants "from the time of the declaration of British sovereignty to the passing of the Constitution Act, 1982, ss. 35(1) and 52 and if it did exist [whether it was] lawfully extinguished." 41 Noting that there is no agreement on the date of the declaration of sovereignty in northwest Saskatchewan, Meagher P.C.J. accepted the Crown's argument that sovereignty was asserted "with the Imperial Order of 1870 when Rupert's Land and the Northwest Territories were admitted into confederation." ${ }^{\text {,42 }}$ At this time, he states, the Crown "arbitrarily divided the Aboriginal community into the two groups - Indian and Half-Breed."43 As a result, "[t]hat division of equals resulted in unequal benefits" and the "Metis have not received and are not receiving the same benefits under the law as the Indian people." 44 Stating that s. 35 is meant to recognize and remedy injustices arising from the artificial nature of these historic divisions he concludes:

I find that the two Aboriginal peoples of northwest Saskatchewan may be distinguished from the rest of society in the area but are not distinct from one another. To grant one Aboriginal people benefits under the law that is not granted to the other gives rise to discrimination under s. 15(1) of the Charter of Rights and Freedoms. ${ }^{15}$

Part I of the Constitution Act, 1982, being Schedule B to the Canada Act 1982 (U.K.), 1982, c. 11.

$R$ v. Morin and Daigneault, [1996] 3 C.N.L.R. 157 at 162 (Sask. Prov. Ct.) [hereinafter Morin]. See also R. v. Perry, [1996] 2 C.N.L.R. 161 (Ont. Gen. Div.).

Morin, ibid. at 165.

Ibid. at 174.

Ibid.

Ibid. at 176. 
Although s. 15 was not argued, Meagher P.C.J. emphasized its application to the Indian and Metis who are "similarly situated' groups of people" who are not similarly treated. ${ }^{46} \mathrm{He}$ urged the "appropriate administrative authorities to resolve the inconsistencies that exist between the two Aboriginal groups by entering into meaningful discussions...." 47 A similar position was advanced by R.C.A.P. when it concluded that the federal policy not to acknowledge that Metis issues fell within their jurisdiction under s. 91(24) of the Constitution Act, 1867 and to exclude them from federal programs is the "most basic current form of governmental discrimination." 48

Among those who advocate Aboriginal equality, there are differences of opinion regarding the potential degree of allowable deviation from judicial constructs of traditional Indian or Inuit life and the significance that should be placed on modern factors in delineating the scope of contemporary rights. For them, same really means equivalent in the sense that the broad outline of activities that are considered Aboriginal may be the same, but the details of contemporary entitlement vary based on actual historic practice, assertion of governmental powers and modern methods adopted by contemporary descendant groups. ${ }^{49}$ Within this vision of equivalent constitutional rights, legal opinions emphasize historical aspects of the right, but also acknowledge the capacity for change. The degree of change possible is the subject of debate. For example, some would argue that the pre-contact Inuit practice of hunting for food with a harpoon translates into a modern right in Labrador Metis to hunt for food using modern technology. ${ }^{50}$ Others argue Aboriginal constitutional rights are not defined so much by historical tracing and maintenance of historic Indian or Inuit traditions as by the application of principles of constitutional law and the relevance of contemporary manifestations of ancestral Indian practices in the lives of Metis people. Adopting the latter theory, European influences and changes in the exercise of traditional practices are properly considered part of the natural growth and reformulation of distinct cultures coming into contact. For example, an unextinguished right to Aboriginal title could support not only the right to exploit the resources of that land in a historic manner, but also the right to $\log$, mine, extract natural resources and so on..$^{51}$ Others argue the latter interpretation is still not flexible enough to capture the fluid nature of Aboriginal constitutional rights. They would take the analysis one step further. For example, they would maintain that the acquisition of revenue is not limited to exploitation of natural resources. Rather all modern usages are integral aspects of Aboriginal title, including usages such as the operation of modern day casinos which are properly characterized as a modern manifestation of a fundamental historic right to occupy and control a land base. $^{52}$ Whichever vision of equivalent Aboriginal constitutional rights is adopted, all are preferable to the previous equality analysis because they give some legal meaning

Ibid. at 177.

Ibid.

Supra note 5 at 219.

For a more detailed discussion see Gibson, supra note 9 at 281-85.

There is some controversy around the Labrador Metis identifying as a distinct Aboriginal people.

See R.C.A.P., supra note 5 at 206-207 and 255-57.

sI Gibson, supra note 9 at 277.

s2 See e.g. debates over the proper characterization of the right in $R$. v. Pamajewon, [1996] 4 C.N.L.R. 164 (S.C.C.). 
to the inclusion of the word "peoples" in s. 35 by contextualizing the interpretation of Aboriginal rights within the contemporary and living cultures of Aboriginal peoples. This article will operate on the assumption that $\mathbf{s .} 35$ may include more contemporary manifestations of original Indian and Inuit institutions. As discussed below in the consideration of domestic Aboriginal rights decisions, this concept of living tradition is pivotal in the extension of existing precedent to support the existence of Metis Aboriginal rights.

It has been argued that because s. 35 Metis rights are rights derived from their Indian and Inuit ancestors, Metis rights are subordinate in constitutional status to Inuit and Indian rights. This argument is based in part on the prevalent misunderstanding that all common law Aboriginal rights are derived from Aboriginal title. Aboriginal title is based in occupation prior to the assertion of sovereignty. A familiar western concept of fairness suggests that in the event of competing Aboriginal interests, prior occupants have stronger claims to land than subsequent arrivals. ${ }^{53}$ This concept of layered title could mean that Metis land rights are subordinate to Indian and Inuit rights in certain territories, but superior to rights of subsequent European settlers. For example, those Metis claiming land rights as descendants of the Metis Nation may have subordinate land claims to descendants of the Cree, Assiniboine and Salteau, but superior rights to the subsequent French, English and Canadian colonizers. However, this concept of layered possessory title fails to reflect actual landholding patterns of Aboriginal populations in Rupert's Land prior to 1870, the effective date of colonization by Canada. It also assumes that Aboriginal title is similar in nature to Anglo-Canadian possessory title, which arises from exclusive possession. Within that proprietary framework, "first in time, first in right" is an ancient and revered organizing principle. $^{54}$ The concept of sui generis, discussed above, highlights the fallacies in this reasoning. As mentioned earlier, this concept originated as an analytical tool to allow judges to break free from the confines of the common law of property to assess the characteristics, scope and content of Aboriginal title. Recent acknowledgment by the Supreme Court that Aboriginal rights may exist independently of Aboriginal title also suggests that use of possessory title principles to prioritize potentially competing Aboriginal interests are not appropriately applied to all Aboriginal rights. ${ }^{35}$

If more legal attention is paid to the term "people" in s. 35, it may be that the rights of the Indian, Inuit and Metis will be domestically construed as equal in constitutional status, but different in content and origin, from the rights of other Aboriginal peoples. This analysis assumes that s. 35 rights are sourced in Indian and Inuit ancestry and existence as distinct peoples. This peoplehood analysis has been adopted by some judges, but has not been endorsed by the majority of the Supreme Court. Although this issue may be unavoidable in the Delgamuukw appeal, the approach to Aboriginal rights in Van der Peet suggests that the peoplehood analysis will not be given significant 
weight in determining the rights of Indian people. ${ }^{56}$ Rather, the focus will be on the Indian or Inuit nature of their rights and the continued practice of traditional Indian or Inuit activities. Therefore, if distinct Metis rights are to be realized, it is clear that a different structure for the analysis of their inherent rights will be required. The degree of difference will depend on the willingness of the court to open up the peoplehood debate in the Metis context. On the one hand, a court may be more willing to address peoplehood while interpreting Metis constitutional rights because Metis political organization fits easily into the European constructs and because British colonial law recognized the ability of inhabitants of a colony to form a government ex necessitate. ${ }^{57}$ To use the words of McEachern C.J., it may not be as easy for a court to conclude that the Metis Nation lived in a "legal and jurisdictional vacuum," particularly if the peak of colonization is used as the effective measure to assess the scope of rights protected in s. $35 .{ }^{58}$ On the other hand, the Supreme Court may continue with a uniform emphasis on the Indian or Inuit nature of s. 35 rights in a way that pre-empts the contemporary exercise of distinct Metis practices and reduces the significance of their inclusion in s. 35 to a cunning political tactic on the part of the federal and provincial governments. ${ }^{59}$ Even without abandonment of the Van der Peet principles by the Supreme Court, Metis constitutional rights will differ substantially in content from the rights of Indian and Inuit peoples. The potential range of distinct Metis rights varies from no rights at all to both Aboriginal ancestral and peoplehood rights. A ruling falling on either extreme of this spectrum would result in their being different rather than equivalent in origin and scope.

Finally, it should be noted that the assumption of equal constitutional status, not just the equal content of Aboriginal rights, can be challenged. The assumption of equal status results in the application of fiduciary principles and other s. 35 principles that affect the continued power of the Canadian government to act to the detriment of Aboriginal peoples and to exercise their rights. Despite the existence of strong legal arguments to the contrary, Canadian judges have upheld the unilateral power of the federal government to terminate Aboriginal and treaty rights prior to their inclusion in s. 35 and to delegate their authority over Aboriginal peoples to the provincial government, absent express treaty rights to the contrary. ${ }^{60}$ The clear elevation of these rights to constitutional status means that their exercise is now protected if they were not effectively terminated prior to 17 April 1982 - the date s. 35 came into effect. The federal and provincial governments cannot interfere with their exercise without a valid legislative objective and without carrying out that objective in a manner that upholds their fiduciary relationship with Aboriginal people. ${ }^{61}$ However, as argued below, if the national and negotiated dimensions of Metis rights are understood, a stricter level of

Delgamuukw v. British Columbia (1991), 79 D.L.R. (4th) 185 (B.C.S.C.), aff d(1993), 104 D.L.R. (4th) 470 (B.C.C.A.), leave to appeal to S.C.C. granted [1994] I S.C.R. vi; and Van der Peet, supra note 4.

57 Gibson, supra note 9 at 285.

s8 Delgamuukw, supra note 56 at 452 .

39 $\quad$ See Flanagan, supra note 2.

60 C. Bell, " $R$. v. Badger: One Step Forward and Two Steps Back?" (1997) 8 Constitutional Forum 21 [hereinafter "One Step"].

61 Sparrow, supra note 7 at 1110. 
scrutiny of government action may be required. This could potentially elevate Metis rights to a constitutional status which many scholars argue should be, but has not yet been, afforded to Indian and Inuit rights. This status is one which maintains that the continuance of s. 35 rights, and the validity of government interference with these rights, can only be determined through negotiation of agreements with Aboriginal people, or through constitutional amendment. ${ }^{62}$ However, this outcome is highly unlikely in the current legal environment.

\section{The Federal-Metis Relationship}

In 1984, Guerin v. $R$. introduced the concept of fiduciary obligation into domestic Aboriginal rights. ${ }^{63}$ The action in Guerin arose from unauthorized federal negotiation of a lease of surrendered Musqueam reserve land. The Supreme Court held that the government of Canada had an equitable obligation, or fiduciary duty, to deal with the surrendered land for the benefit of the Musqueam people and that it was in breach of that obligation. The nature of this duty was "trust-like" and arose because of the inalienable nature of Aboriginal title and the surrender provisions of the Indian Act. ${ }^{64}$ Of particular importance in the reasoning of Dickson J., as he then was, was the fact that the reserve land was inalienable to persons other than the Crown. Counsel for the Crown maintained that if a trust-like obligation existed, it was merely political and unenforceable by the courts. Invoking the equitable jurisdiction of the court, the majority rejected this argument and found that an enforceable equitable obligation arose from s. 18(1) of the Indian Act. Section 18 imposes a legislated obligation on the federal government to act for the benefit of the Indians in the surrender process and gives them discretionary powers over the use of surrendered lands. However, in his majority opinion, Dickson J. extended the concept of fiduciary obligation beyond the confines of s. 18 and said the following about the source of federal equitable obligations:

where by statute, agreement, or perhaps by unilateral undertaking, one party has an obligation to act for the benefit of another, and that obligation carries with it a discretionary power, the party thus empowered becomes a fiduciary. Equity will then supervise the relationship by holding him to the fiduciary's strict standard of conduct. ${ }^{6 s}$

Subsequent to Guerin, many tried to limit fiduciary analysis to the circumstance of surrendered lands and legislated obligations. However, the reasoning in Guerin and Sparrow supports the existence of a more general fiduciary duty that cloaks all dealings between Aboriginal peoples and the Crown. Again, in the words of the former Chief Justice in Sparrow: 
The sui generis nature of Indian title and the historic powers and responsibility assumed by the Crown constituted the source of such a fiduciary obligation.... [T] he Government has the responsibility to act in a fiduciary capacity with respect to aboriginal peoples. The relationship between the government and the aboriginals is trust-like, rather than adversarial, and contemporary recognition and affirmation of aboriginal rights must be defined in light of this historical relationship. ${ }^{66}$

As Gibson notes, not only does this reasoning "appear to extend beyond Indian lands, surrendered or otherwise," but the Court's use of "the term Aboriginal peoples [also] suggests that the duty is not restricted to Indian peoples." ${ }^{167}$ Because the reference to "peoples" in s. 35 has both historical and contemporary significance, this duty can be extended to the Metis Nation and other Metis peoples. ${ }^{68}$ This understanding of the potential scope of the Crown's equitable obligations is also in keeping with the spirit of Guerin which cautioned that the "categories of fiduciary, like those of negligence, should not be considered closed." 69

Increasing support for the inclusion of Metis in the interpretation of the term "Indians" in s. 91(24) of the Constitution also supports the application of fiduciary analysis to the federal-Metis relationship. ${ }^{70}$ Section $91(24)$ provides that the federal government has jurisdiction over "Indians, and Lands reserved for the Indians." Although the federal government has historically limited the exercise of this jurisdiction to status Indians living on reserves, it is clear that s. 91(24) encompasses a larger group of Aboriginal peoples than those included in the federal Indian Act regime. Judicial opinion supports the inclusion of Inuit peoples and federal policy has changed to accommodate that opinion." However, clear direction has yet to be given by the Supreme Court on the inclusion of the Metis. Despite limited judicial consideration on this point, many scholars look to principles of constitutional interpretation, judicial opinion, pre- and post-Confederation legislation and federal practice to support arguments that Metis are properly included in a prospective interpretation of s. 91(24). After commissioning extensive research on this topic, R.C.A.P. was "convinced that all Metis people, whether or not they are members of full-fledged Aboriginal nations, are covered by s. 91(24)."72 In their opinion, the federal government's refusal to acknowledge this "reflect[s] the mistaken view that there are only two major groups of Aboriginal peoples in Canada, First Nations and Inuit."'3 It also perpetuates the "most

Supra note 7 at 1108 [emphasis added].

Gibson, supra note 9 at 294.

The emphasis here is on the federal-Aboriginal relationship. However, it can be argued a similar obligation extends to the provinces. See L.I. Rotman, "Provincial Fiduciary Obligations to First Nations: The Nexus Between Governmental Power and Responsibility" (1994) 32 Osgoode Hall L.J. 735.

Supra note 63 at 137.

There has been a substantial amount of research on this topic. For an up-to-date consolidation of academic and judicial opinion see R.C.A.P., supra note 5, vol. 5, c. 5 at 209 (appendices). See also R.C.A.P., Aboriginal Self-Government: Legal and Constitutional Issues (Ottawa: Canada Communications Group, 1995) at 140-375.

Re Eskimos, [1939] S.C.R. 104.

RC.A.P., supra note 5 at 209.

Ibid. at 199. 
basic current form of governmental discrimination."74 Why is this discrimination? Because the practical effect of federal policy has been the exclusion of Metis from contemporary programs and negotiation processes designed for the benefit of Aboriginal peoples. The result is Metis are in the difficult position of proving all rights in court, or relying on the political will of provincial governments which are significantly influenced by local opinions of non-Aboriginal citizens. The result has been inequality of treatment of Metis by provincial governments across the country.

Prior to the infusion of fiduciary language into Aboriginal rights analysis, it was generally accepted that powers given to Parliament under s. 91(24) were permissive, not mandatory. This is in keeping with the general reluctance of courts to impose positive legal duties requiring the undertaking of specific actions. ${ }^{75}$ Consequently, without consideration of the fiduciary nature of the federal-Metis relationship, acceptance of federal jurisdiction over Metis does not necessarily remove Metis from the precarious position of relying on political will to operate in their best interest. However, the invocation of the fiduciary principle changes the likelihood of this outcome. As fiduciary responsibilities in other constitutional contexts "have long been recognized to be positive as well as negative," there is no logical reason why positive obligations should be excluded from the analysis of federal-Aboriginal fiduciary relationships. ${ }^{76}$ Applied to federal treatment of Metis people, this could mean that the federal government has a general equitable obligation to treat Metis people as equivalent to other Aboriginal people - a general obligation which is supported by $\mathbf{s}$. 35 and would require the extension of government programs to the Metis.

The positive nature of the general federal obligation is described by Dale Gibson as follows:

It is a legal axiom that rights and obligations are correlative. Thus, it would be meaningless, in a legal sense, to assert that someone had a right unless someone else had an obligation to do something that would permit that right to be realized or to refrain from doing anything that would prevent its realization. If I have a legal right to be paid by you, you must have a corresponding obligation to pay me.... Section 35(1) of the Constitution Act, 1982 recognizes and affirms existing Aboriginal rights. Since rights and obligations are correlative, section 35(1) must recognize and affirm an implicit obligation on someone's part to refrain from suppressing those rights and perhaps even to contribute positively to their realization. ${ }^{n}$

Although most judicial opinions following Sparrow raise fiduciary language in the analysis of Aboriginal rights, little meaning is given to this concept unless the Crown is in a circumstance where it must justify continued federal interference with an "existing" Aboriginal right protected by the constitution or a specific obligation is identified by legislation, agreement or treaty. The latter sources of obligation, referred to in contemporary federal policy as Guerin-type obligations, also receive some

Ibid. at 219.

Positive duties require someone to undertake a particular action and negative ones prohibit actions. Gibson, supra note 9 at 296.

Ibid. at 293. 
attention in the negotiation of specific claims with First Nations. Arguments drawing from Guerin and the historical treatment of Metis peoples suggest that Guerin-type obligations should also extend to the Metis even if they are not covered by a general cloak of fiduciary law as a result of inclusion in s. 35(1) and s. 91(24). It is beyond the scope of this article to list all potential sources of specific federal obligations to the Metis. However, three examples illustrate the potential implications of recognizing the full scope of federal equitable obligations. The first example arises from the historical circumstances of scrip distribution and its effect on descendants of the Metis Nation. The second relates to breach of treaty obligations with other Metis. The third example arises from the suggestion in Guerin that enforceable equitable obligations may also arise from unilateral undertakings in which the federal government indicates its intention to act for the benefit of the Metis.

Substantial academic commentary has been generated on the nature and extent of fiduciary obligations arising from s. 31 of the Manitoba Act, $1870 .{ }^{78}$ Section 31 provided that 1,400,000 acres of land was to be divided among "the children of the half-breed heads of families" towards the "extinguishment of Indian title" and "for the benefit of the families of the half-breed residents" of Manitoba. Section 31 contained an express obligation on the federal government to act for the benefit of the Metis and carried with it a discretionary power for the method of land allocation and distribution. The method chosen was scrip distribution - a system which involved the issuance of certificates that could be exchanged for money or individual allotments of land. Obligation coupled with discretion are the two elements identified in Guerin as central to the existence of an equitable fiduciary obligation. So, even if the Courts fail to accept the inclusion of the Metis in the federal-Indian relationship anticipated in s. 91(24), this failure does not have to be detrimental to an assertion of rights arising from fiduciary obligation. Metis inclusion in s. 35 and the reasoning in Guerin and Sparrow provide ample support for recognition of a fiduciary relationship and enforceable obligations resulting from enactment and implementation of obligations anticipated in s. 31 of the Manitoba Act.

The more difficult questions are whether or not the federal obligation has been breached, what standards should be applied to determine whether a breach has occurred, and what range of remedies are Metis people entitled to seek. The fact that the Manitoba Act resulted from negotiations with the Metis Nation, and might even be considered a treaty, raises the possibility of applying a stricter standard of conduct than might otherwise be applied to breaches of unilateral undertakings as the exchange of promises should increase the relevance of honourable Crown conduct in the eyes of equity. ${ }^{79}$ Regardless of the success of arguments for stricter standards, the unconscionable actions of federal government officials in the handling of the scrip distribution system suggests that the federal obligation to Metis people was breached.

Supra note 34.

For further discussion see "One Step," supra note 60. For a more detailed discussion of fiduciary law see L.I. Rotman, Parallel Paths: Fiduciary Doctrine and the Crown-Native Relationship in Canada (Toronto: University of Toronto Press, 1996) [hereinafter Parallel Paths]. See also, infra note 121 . 
Because the fiduciary obligation is constitutional in nature and has not been properly met - and thereby exhausted - it arguably continues as an equitable obligation with a corresponding constitutionally protected right to enforcement. The most recent support for this conclusion is found in the Report of the Royal Commission on Aboriginal Peoples. In its opinion:

The government of Canada owed a fiduciary obligation to the members of the Metis Nation.... [It] was legally responsible to act in the best interests of Metis people and not to place its own interests, or those of non-Aboriginal persons, ahead of Metis interests. Its tolerance or reckless ignorance of, and occasional complicity in, the schemes by which many Metis were effectively stripped of their Manitoba $A c t$ benefits is difficult to reconcile with that fiduciary responsibility. ${ }^{80}$

\section{Also in their words:}

[I]t is unquestionable that the governments of Canada and the prairie provinces must bear paramount responsibility for the lack of an adequate Metis land and resource base today. These are the indisputable facts:

- The verbal promises made to the Manitoba Metis were never fulfilled.

- The benefits that were eventually bestowed under the Manitoba Act and Dominion Lands Act were so long delayed, for the most part, that their value was severely eroded by a huge influx of new settlers grabbing up much of the choicest land and by the decision of many discouraged Metis to migrate further westward.

- The "market transactions" whereby many Metis were stripped of their land were marked by sharp dealing and fraud on the part of private land agents and occasionally of government officials.

- The government of Canada was aware that such sharp dealing and fraud was being practised on a large scale but failed to take effective steps to prevent it or to compensate for it. ${ }^{81}$

Other Metis may also have rights arising from breach of fiduciary obligations. Treaty Commissioners provided assurances to "the Chiefs of the various bands, that they dealt with, that the 'half-breeds' connected with those treaties would be 'treated fairly and justly."'82 Other Metis were actual signatories to treaties or treaty adhesions. Descendants of others also find themselves on the receiving end of arguments that their "Aboriginal" rights to land have been terminated by treaties with First Nations, even though Metis were not signatories to those treaties and were identified as distinct from the Indian signatories at that time. The latter position flows from the finding in Bear

st Ibid. at 247-48. For more detailed discussions see P. Chartrand, Manitoba's Metis Settlement Scheme of 1870 (Saskatoon: Native Law Centre, University of Saskatchewan, 1991); D.N. Sprague, "Government Lawlessness in the Administration of Manitoba Land Claims" (1980) 10 Man. L.J. 415. For arguments supporting fulfilment of federal obligation see T. Flanagan, Metis Lands in Manitoba (Calgary: University of Calgary Press, 1991). 
Island that Aboriginal land rights can be extinguished by treaty without proper representation of all Aboriginal peoples in the territories affected. ${ }^{83}$ However, in that case the Supreme Court also suggested that such action on the part of the Crown could be a breach of its fiduciary obligation to the people negatively affected and that extinguishment without proper representation may also generate arguments to support breach of a general fiduciary obligation. Subsequent decisions have also suggested that breach of specific treaty obligations may also invoke fiduciary analysis as it is "always assumed that the Crown intended to fulfil" those obligations. ${ }^{84}$

Undertakings independent of legislation and treaty-making may also generate enforceable equitable obligations. For example, promises given in the establishment of Saint Paul-des-Metis could be enforceable legal obligations vis-à-vis those descendants of the original Metis inhabitants who lost land and benefits when the colony was opened for settlement. The history of Saint Paul-des-Metis is complex and involves dishonourable conduct by many involved. However, a brief review of the settlement history reveals the presence of three key factors in fiduciary analysis: a promise to act for the benefit of an Aboriginal people, discretion in carrying out that promise and breach. ${ }^{85}$

As a result of extensive lobbying by Reverend Father Albert Lacombe, in December 1895 the federal government passed Order-in-Council 3723 setting aside two townships "with a view to their being subdivided into forty acre lots for the use of destitute Metis. ${ }^{186}$ Responding to announcements about the new settlement by Father Lacombe, many Metis, poverty-stricken and demoralized after the North-West rising of 1885 , came to Saint Paul-des-Metis with the hope of acquiring food and land. Some even withdrew from treaty. The Order-in-Council also provided for the settlement to be managed by a board of Roman Catholic bishops and lay trustees and enabled the church to erect and maintain an industrial school. Except for a modest grant from the federal government for seed and machinery, the government was clear that its promise to Father Lacombe and the Metis would involve no further financial outlay. By the early 1900 s it was apparent that more financial help would be required but both the federal and Territorial governments denied responsibility. When the school finally opened in 1903, it was without any public support from Ottawa. Even members of the Territorial government questioned whether the federal government could "get rid of its obligations to these former wards by allowing them to withdraw from Treaty ... to a freedom and perils of which they were certainly most sublimely ignorant." ${ }^{\text {"77 }}$ Two years later the school was burned to the ground by "Metis boys who resented the disciplined and regular life to which they were subjected in the school." ${ }^{\text {"88 }}$ After the burning of the school, Father Therien, who was managing the settlement, seemed to lose his passion

Ontario (A.G.) v. Bear Island Foundation, [1991] 3 C.N.L.R. 79 (S.C.C.) at 81.

R. v. Badger, [1996] 2 C.N.L.R. 77 at 92 (S.C.C.).

For a detailed discussion of the history of Saint Paul-des-Metis see G. Stanley, "Alberta's HalfBreed Reserve Saint Paul-des-Metis 1896-1909" in A. Lussier \& D.B. Sealey, eds., The Other Natives (the-les Metis), vol. 2 (Winnipeg: Manitoba Metis Federation Press, 1978) 75.

Ibid. at 81.

lbid. at 93 .

Ibid. at 97 . 
and, some suggest, intentionally started to aid in the movement of French-Canadian settlers into the settlement area. Despite vocal opposition and questioning by Metis settlement members, Father Therien told Frank Oliver, the Minister of the Interior, that the Metis would not oppose the opening of Saint Paul-des-Metis to settlement. The Minister of the Interior made no attempt to directly consult the Metis. In the end, after ten years without the Metis inhabitants being properly informed or consulted, Saint Paul-des-Metis was opened to settlement. As was the case in allotting lands under the scrip distribution system, the distribution of colony lands was manipulated to deprive the Metis of current holdings. Father Therien, in collaboration with Frank Oliver, made sure French-Canadian applicants were informed and given the first opportunity to select lands thereby significantly limiting the number of Metis applicants.

\section{EQuitable Aboriginal Rights}

The existence of equitable federal obligations affirmed by s. 35(1) arguably carries with it a corresponding equitable entitlement to fulfilment of those obligations, or some other form of compensation. The appropriateness of the equitable remedy may vary from a demand that the federal government make existing practices more inclusive to demands that they refrain from particular actions that interfere with those rights to monetary compensation. Consideration of equitable remedies suggests that $\mathrm{s} .35$ is not only a confirmation of pre-existing Aboriginal and peoplehood rights, but is also an affirmation of equitable obligations and corresponding equitable rights to enforcement of those obligations. The significance of this affirmation to the government's ability to ignore or interfere with equitable remedial rights is unclear. It may depend on the characterization of those obligations as positive or negative, the identification of the corresponding equitable remedies and the ability of the court to compel government action. $^{89}$ If the obligation at issue is negative - that is, an obligation of noninterference - then lack of action is not a breach and there is no corresponding right to an equitable remedy. If the obligation at issue is a positive specific equitable obligation such as the Guerin-type obligations, constitutional affirmation may have greater significance. However, the nature of that significance is unclear. The formula created to balance s. 35 rights and state objectives suggests that interference with s. 35 rights can be justified. However, the test in Sparrow was developed in the context of controlling government actions affecting what were historically common law rights. It was not designed in a context that directly concerned equitable fiduciary obligations and the fundamental corresponding equitable rights. Although Sparrow allows interference with s. 35 rights in furtherance of a valid legislative objective, the second branch of the justification test renders its application to equitable constitutional rights and obligations nonsensical. This branch requires that the implementation of the government objective be carried out in a manner that upholds the government's fiduciary obligation to Aboriginal peoples. Even though it can be argued that the second branch of the test has been given little substantive meaning by the current Supreme

Although the remedy to compel action exists in equity it has not yet been enforced against the Crown. Rather, the court will declare actions legal or illegal and declare the existence of rights in the expectation of Crown compliance. For a more detailed examination of potential remedies see Parallel Paths, supra note 79 at 195-98. 
Court, it is illogical to assume that the government can justify continued breaches of fiduciary obligation to the detriment of specific equitable rights or remedies and at the same time fulfil that obligation. ${ }^{90}$ So, for example, the federal government could not argue in Guerin that the breach of its obligation to act for the benefit of the Musqueam people in the leasing of their surrendered land would be justified. Rather, breach automatically gives rise to an equitable remedy in favour of the Musqueam.

This conceptual difficulty around the status of constitutional equitable obligations and equitable remedial rights is one of several reasons why it is dangerous for Metis constitutional rights to be reduced to those within the realms of equity and outside the scope of common law. Fiduciary law is in its embryonic stages as it applies to the Crown-Aboriginal relationship and s. 35 rights. The courts have yet to decide what positive actions, if any, fiduciary obligation will compel. It is also uncertain whether this concept will be used in a general sense to cloak all federal-Aboriginal relationships or whether it will be confined to breaches of specific federal and provincial promises. Further, equitable remedies are always at the discretion of the court. Although breach may automatically give rise to some type of remedy, that remedy may not necessarily involve compelling government action, delivering up of land or monetary compensation. Finally, because of these possibilities, constitutional equitable rights and obligations may be folded into the theories of moral and political obligation that prevailed in the pre-Guerin era. This would cast what would otherwise be considered illegal government action into the realm of immoral conduct deserving of redress not necessarily in the courts, but at negotiating tables concerned with political fairness. Although equitable rights are not legal rights in the narrow understanding of that phrase as it is used in law to identify principles originating in the early English common law courts, they are legal in the contemporary sense of the term; that is, they are justiciable and enforceable at the discretion of Canadian courts. However, even R.C.A.P. in its condemnation of government action is reluctant to recognize that breach of legal fiduciary duties gives rise to enforceable equitable obligations. This is evident in their ultimate conclusion that: "[w]hatever the legal situation, it is clear ... that the Metis Nation is entitled, both morally and politically, to have access to land bases and land use rights sufficient to fulfil its legitimate aspirations as an Aboriginal people."

\section{INHERENT METIS RightS}

Another important contribution by the Sparrow case to the development of Canadian Aboriginal rights law is the creation of an interpretive framework which emphasized a broad, liberal and generous interpretation of s. 35(1). Sparrow also highlighted the need to interpret Aboriginal rights flexibly so as to allow their exercise in a contemporary manner. Characterizing Aboriginal rights as those rights that are an integral part of the distinctive culture of an Aboriginal group, Sparrow cautions that Aboriginal rights must be defined in a manner that is "sensitive to the aboriginal Paternalism and Fiduciary Rhetoric in Badger and Van der Peet" (1997) 8 Constitutional Forum 40.

R.C.A.P., supra note 5 at 247. 
perspective of the meaning of the rights at stake." ${ }^{92}$ In assessing the significance of s. 35, the Supreme Court also held that constitutional recognition and affirmation protects existing Aboriginal rights from the exercise of government power. Quoting Professor Lyon, the former Chief Justice agreed that "section 35 calls for a just settlement for aboriginal peoples. It renounces the old rules of the game under which the Crown established courts of law and denied those courts the authority to question sovereign claims by the Crown. ${ }^{993}$ The new rules generated by s. 35 are intended to reconcile Crown sovereignty with prior Aboriginal occupation. ${ }^{94}$ In Sparrow, this reconciliation is achieved through the application of a justification test to determine the validity of government interference with rights not effectively extinguished by the Crown prior to their protection in s. 35. The justification test has two parts. First, the Aboriginal claimant must prove the existence of an Aboriginal right and that the legislation at issue interferes with the exercise of that right. The onus then shifts to the Crown to justify its interference. This part of the test has two branches. First, the Crown must establish that it is acting in furtherance of a valid legislative objective. Second, it must show that this objective is attained in $\downarrow$ manner that is consistent with the honour and fiduciary obligation of the Crown to act for the benefit of Aboriginal people.

The interpretive guidelines in Sparrow have been used to support Metis claims to Aboriginal title and land use rights. The reception of these arguments by academics and lower courts ranges from complete rejection to the assumption that all of the Sparrow principles apply to Metis by virtue of Metis inclusion in s. 35. Indicative of the first extreme are the obiter comments of Muldoon J. in Sawridge where he reflected on the definition of Aboriginal peoples in s. 35(2). In his opinion:

the Metis can hardly be thought of as "Aboriginal," having been people only since the advent of the European people and then called "Half-breeds" because of their mixed ancestry. The constitution makers indulged in history's revision here."

Those who oppose this view point to Aboriginal ancestry and the fact that Aboriginal rights inhere to contemporary Aboriginal peoples. They maintain that s. 35 Metis rights are inherited from their Indian ancestors who lived in organized societies and occupied Canada before the assertion of English sovereignty. Central to this theory is the treatment of Metis collectivities, including the Red River Metis, who in the late eighteenth century emerged as a distinct national entity, part of a dynamic Aboriginal culture that changed and reformulated into various distinct groups as a result of their interaction with Europeans. This argument has resurfaced several times in legal and political discourse since it was placed before the Canadian government by Father Ritchot in 1870 during negotiations surrounding the admittance of Manitoba into

Ibid. at 1106.

Van der Peet, supra note 4 at 193.

Sawridge Band v. Canada, [1995] 4 C.N.L.R. 121 at 141 (F.C.T.D.). This decision has been sent back for a new trial on the basis that the decision of Muldoon J. was biased. See also the discussion in "Metis People," supra note 5 at 367-68. 
Confederation. ${ }^{96}$ Interpreted in this context, the reference to "Indian title" in s. 31 of the Manitoba Act could be construed as express recognition of the Metis' inherent right to Aboriginal title derived from their Aboriginal ancestry.

The Aboriginal ancestry theory, when combined with domestic Aboriginal rights law, suggests that Metis Aboriginal rights may be limited to descendants of those Metis who:

(a) trace their ancestry to an Aboriginal group in prior occupation of lands over which Metis rights are asserted; and

(b) can establish that the alleged right was, and continues to be, integral to their Indian/Metis lifestyle.

An argument for the lifestyle distinction could be based in the colonial practice of treating those Metis who lived like, or among, the Indians differently from those who lived a more blended agrarian or European lifestyle. Metis of the former category were included in treaty-making processes such as the negotiations of the Robinson Huron Treaties in 1850 and the Half-Breed Adhesion to Treaty 3 in 1875. Although the treaties themselves refer to Metis entitlement arising "by virtue of their Indian blood," it could be argued that that treaty was extended only to those Metis who chose a predominantly traditional Indian lifestyle and were expected eventually to assimilate with Indian communities. Those who lived more agrarian lifestyles or who lived by the buffalo hunt (or both) were dealt with through the scrip distribution system. However, it is argued here that their rights are not properly understood as Aboriginal or "Indian" in origin. Rather, their rights are similar to possessory rights attributed to the original white settlers of the Red River. Alternatively, they are properly understood as rights which arose as a result of negotiations between nations or governments. Adopting this perspective, s. 31 of the Manitoba Act is properly construed as a source of delegated land rights to the original settlers in the Red River, a treaty or legislated confirmation of negotiation of rights attributed to settlers who improved the land and ruled themselves ex necessitate. It is not properly understood as recognizing or acknowledging Indian ancestral rights of the Metis. Indeed, it is even argued that the Metis themselves did not advance claims for Aboriginal rights in negotiations with the federal government. Rather, Father Ritchot was the first to claim that they had Aboriginal rights as descendants of the Indians and was acting outside the scope of his authority when he agreed to the terms of $\mathbf{s}$. 31. Following this line of reasoning, the inclusion of the phrase "towards the extinguishment of Indian title" in s. 31 is best understood as a thoughtless concession and quick solution to resolve problems with the Metis so that the Prime Minister could follow through with his plans to extend the railway further west - an injustice perpetrated a second time during the negotiations of $\mathbf{s} .35$ of the constitution. ${ }^{97}$

$7 \quad$ T. Flanagan, Riel and the Rebellion: 1885 Reconsidered (Saskatoon: Western Producer Prairie Books, 1988) at 59. Contra D. Sprague, Canada and the Metis 1869-1885 (Waterloo: Wilfrid Laurier Press, 1988). See also discussion in Gibson, supra note 9 at 278-80. 
Another rationale advanced for drawing lifestyle distinctions is that the Dominion of Canada would have reserved land to the collective use of the Metis Nation rather than satisfy their interests through individual allotments of land if those interests had been considered Aboriginal in nature. However, provisions in the Manitoba Act and representations made by Sir John A. Macdonald to the House of Commons suggest that an equally viable interpretation is that "many Metis had claims to land in addition to an Aboriginal right - that as settlers of established farming areas." the Manitoba Act may carry with it at least two purposes: the handling of claims arising from Indian ancestry and the negotiation of individual property rights arising from possession and improvement of lands. ${ }^{99}$ Numerous other arguments can also be raised to refute distinctions based on the employment of the scrip distribution process including:

(1) The Metis Nation understood that they were to be granted lands as individuals, but the land granted was to be assembled into Metis townships or reserves;

(2) Individual grants were also consistent with the government's general Indian policy of "civilizing";

(3) The government was likely influenced by the policy of the United States government, which at the time was attempting to break up tribal organization through individual land allotments, a system subsequently applied to Indians on Canadian reserves;

(4) The fact that scrip was available to original white settlers does not mean that the Metis are not Indians; it means that the method used to address their particular circumstances was not unique;

(5) When viewed in the context of the Manitoba Act as a whole, s. 31 is properly understood as one provision in a treaty negotiated between nations; ${ }^{100}$ and

(6) The federal government did attempt to set up a reserve in 1895 when it realized that the scrip distribution system had failed.

Although some of the above assertions are disputed interpretations of historical events, placing such importance on the recognition of rights as "Aboriginal" and the process for settling the claims of the Metis Nation is clearly refuted by recent decisions of the Supreme Court.

D.B. Sealey, "Statutory Land Rights of the Manitoba Metis" in Lussier \& Sealey, supra note 85, 1 at 4 [emphasis added].

99 I say at least two because this article is limited in its scope to a domestic framework. It has been argued that the Manitoba $\mathrm{ACt}$ is a treaty negotiated between the governments of two nations and that the appropriate framework to apply is the law of nations. See e.g. R.C.A.P., supra note 5 at 288-89 and Dumont, supra note 3 per O'Sullivan J. dissenting. 
Another flaw in the above argument is the assumption that Metis knowledge of the legal nature of their rights and recognition of their rights as Aboriginal by colonizing governments is relevant in determining the existence of the Aboriginal rights of their Metis descendants in contemporary domestic law. Aboriginal rights protected by $s$. 35(1) of the Constitution Act, 1982 are derived from historical as well as contemporary legal and political circumstances. History is important because Aboriginal rights originate in the social organization of Aboriginal societies that existed before colonization. However, not only does the inherent nature of Aboriginal rights pre-empt the notion that they are contingent upon government recognition, Canadian law has never maintained that the existence of contemporary Aboriginal rights is contingent on Aboriginal understandings of the intricacies of colonial law. Rather, the perception of the Aboriginal right by Aboriginal populations is relevant insofar as it assists in bringing contemporary judicial constructs of rights in line with Aboriginal understandings of the historical and contemporary nature of the right at stake. ${ }^{101}$ This position is supported by Lamer C.J.C. who urges in the Côté decision that definitions of constitutional Aboriginal rights based only on historical practice of recognition run contrary to the purpose of s. 35 . In his words:

Section 35(1) would fail to achieve its noble purpose of preserving the integral and defining features of distinctive Aboriginal societies if it only protected those defining features which were fortunate enough to have received legal recognition and approval by European colonizers. I should stress that the French Regime's failure to recognize legally a specific Aboriginal practice, custom or tradition (and indeed the French Regime's tacit toleration of a specific practice, custom or tradition) clearly cannot be equated with a clear and plain intention to extinguish such practices under the extinguishment test of s. 35(1).... Indeed, the respondent's proposed interpretation risks undermining the very purpose of s. 35(1) by perpetuating the historical injustice suffered by Aboriginal peoples at the hands of colonizers who failed to respect the distinctive cultures of pre-existing Aboriginal societies. ${ }^{102}$

Although Côté can be distinguished because it concerned a conflict between French and English colonial law, analogous arguments can be extended to the Metis Nation if judicial attention is directed to the purposes of s. 35. If one understands $s .35$ as preserving "integral and defining aspects of Aboriginal societies" and has a sense of the historical injustices suffered by the Metis Nation, it is difficult to imagine how s. 35 can be interpreted to allow a denial of Metis Aboriginal rights solely on the basis that they did not perceive their rights to be Indian in origin or that their rights were not recognized as Indian rights by England or the Dominion of Canada in 1870. The proper question for the court is not whether the colonizers and Metis conceptualized Metis rights as Indian rights, but whether s. 31 of the Manitoba Act, and subsequent federal actions, clearly and plainly terminated whatever rights the Metis may have had.

In addition to arguments based on recognition and process, the concept of inherent rights is used to anchor the existence of contemporary rights in the continued centrality of traditional Indian activities in Metis culture. This line of reasoning is reflected in 
lower court decisions which recognize Aboriginal rights in those Metis who follow "lifestyles which kept them 'close to the land"."103 For example, in McPherson, Gregoire J. identifies these Metis as "fringe Metis" and in Blais, Swail P.C.J. defines them as "Metis effectively living on the fringes of a status Indian reserve, and following a lifestyle closely akin to that traditionally associated with Native Indians." 104 Similarly, in Morin, Meagher J. held that the Metis accused could have Aboriginal rights because, although they were "categorized as Metis," their historic and contemporary lifestyle was not distinct from that of other Aboriginal peoples living in northern Saskatchewan. ${ }^{105}$ However, the problem with this type of analysis becomes apparent for all Aboriginal peoples when combined with the tendency of Canadian judges to characterize institutions and activities as Aboriginal only if they existed at the date sovereignty was asserted and continue to exist in the same manner. This theory, known as the "frozen rights theory," does not necessarily exclude the Metis Nation or other self-identifying Metis populations from the Aboriginal rights regime if the exercise of their "Indian-like" activities is traced through their Metis ancestry to their original Indian ancestors. Their Indian ancestors clearly were here before sovereignty was asserted. Accepting this analysis, if a Metis can establish that his or her Indian ancestors fished for sustenance and his contemporary Metis community still fishes for sustenance, then a Metis Aboriginal right to fish for sustenance may continue to exist if it has not been effectively terminated by government action. ${ }^{106}$

Greater emphasis must be given to the fluid nature of Aboriginal culture. This result can be accomplished through emphasis on the Sparrow principle that s. 35 rights must be interpreted "flexibly so as to permit their evolution over time." ${ }^{107}$ Greater emphasis on the fluid nature of culture enables the categorization of unique Metis institutions as modern manifestations of fundamental and historic Indian institutions. To illustrate the potential impact of frozen and fluid interpretation, consider as an example the institution of the buffalo hunt. Although aspects of Metis organization and discipline may be distinct to Metis populations, the hunt is also a traditional Indian activity which was governed by the existence of social norms, the use of force and ostracism. In their discussion of crime and punishment in Aboriginal societies, Hamilton A.C.J. and Sinclair A.C.J. discuss some of the similarities of the Assiniboine and Metis hunt as follows:

The role of elders and their regular use of shame and expulsion in Ojibwa, Assiniboine and Cree society illustrates how "force," defined broadly to include mild sanctions, was used in these cultures. Roman Catholic missionary Father de Semet [1801-1873] described how Assiniboine Indians in Manitoba and adjoining lands disciplined offenders in the hunt: "Their guns, their bows and arrows were broken, their lodges cut in pieces, their dogs killed and their hides are taken from them. If they are bold enough to resist the penalty, they are beaten with bows, sticks and clubs."

Blais, supra note 2 at 122.

R. v. McPherson, [1993] 1 W.W.R. 415; and Blais, ibid.

Supra note 41 at $174-77$.

See e.g. Gibson, supra note 9 at 283.

Supra note 7 at 1093. 
The Metis of Manitoba conducted their buffalo hunt in a fashion that reinforces de Semet's observations. Alexander Ross, a leading citizen of the Red River, recorded the rules of the hunt in the 1840s:

1. No buffalo to be run on the Sabbath-day.

2. No party to fork off, lag behind, or go before, without permission.

3. No person or party to run buffalo before the general order.

4. Every captain with his men, in turn, to patrol the camp, and keep guard.

5. For the first trespass against these laws, the offender to have his saddle and bridle cut up.

6. For the second offence, the coat to be taken off the offender's back, and be cut up.

7. For the third offence, the offender to be flogged.

8. Any person convicted of theft, even to the value of a sinew, to be brought to the middle of the camp, and the crier to call out his or her name three times, adding the word "Thief" at each time. ${ }^{308}$

If a fluid theory of rights is adopted, it could be argued that because the Metis buffalo hunt is like the hunt exercised by the Assiniboine Indians in Manitoba, it is properly considered a reformulation of the Indian tradition to hunt buffalo in an organized manner, or perhaps even as a different manifestation of "traditional" Aboriginal justice. These positions are reinforced if placed in the context of life in Manitoba from the early 1600 s to 1870 . This was a time when Aboriginal people lived according to Aboriginal laws, or in the case of the Metis Nation, the merger of two legal systems, until systems more akin to those in Britain and Europe were forcefully imposed. ${ }^{109}$

On the other hand, a frozen concept of rights could result in an assessment of Metis Aboriginality that measures the degree to which Metis social institutions conform with traditional Indian culture. Adopting this yardstick, an equally plausible conclusion in comparing the hunt of the Assiniboine and Metis would be that the Metis buffalo hunt is not Aboriginal to the extent that it varies from the specific rules and practices adopted by the Assiniboine. If the rules are separated from the activity of the hunt, and emphasis is placed on the degree to which the Metis rules are similar to those of their European ancestors, a similar result occurs. Beating with "bows, sticks and clubs" is considered substantially different from the Metis practice of flogging, and being shamed by elders is not treated as equivalent to having your name called out three times "adding the word 'Thief,' at each time." Dissecting the Metis institution of the hunt into European and Indian segments could also result in a ruling that the only Aboriginal aspect of the Metis hunt was hunting for food and trade. Only this aspect of the Metis hunt would be properly recognized and protected as a Metis Aboriginal right. As discussed below, the revival of frozen rights theory and the direction to shave off all European influences in attempts to uncover Indian practices further reduces the Aboriginal aspect of the hunt to hunting buffalo for food. Imagining for a moment a world in which buffalo are still available to hunt, s. 35 protects the Indian and Metis 
right to continue to hunt buffalo for food without government interference, unless such interference can be justified under the Sparrow test. To the extent that they lead a life akin to judicial constructions of traditional Indian life, Metis are Indians and have Aboriginal rights; to the extent they are different, they are not viewed as Aboriginal. Non-Aboriginal activities are not within the scope of $s .35$ protection. ${ }^{110}$

This tendency to freeze Aboriginal society at a particular point in time and to reject the classification of social institutions as Aboriginal because they are similar to European institutions, or are influenced by them, is not sourced in British colonial law. Rather, it is a modern restriction arising from federal policy and subsequently imposed as "law" by the domestic Canadian law of Aboriginal rights. Prevalent in its colonial origins, but missing in Canadian law, is an appreciation of the diversity of Aboriginal culture and recognition that existence as a people in occupation of land, regardless of the form of social organization, generates a vast array of rights to land use and governance. This is evident in the reasoning of the Marshall court in early United States decisions applying British colonial laws which, despite their express incorporation into domestic law, were ultimately ignored by American politicians and Canadian courts."' For example, the lack of emphasis placed on traditional Indian life in assessing the entitlement of the Cherokee to live undisturbed in their territories is abundantly clear in several decisions rendered by the Marshall court in the 1830s. In assessing the extent of state jurisdiction over the Cherokee, the Marshall court refused to enhance their jurisdiction by limiting the rights of the Cherokee to only those rights necessary to enable them to exercise a traditional life. Indeed, the right of the Cherokee to adopt and control the role of European institutions in their lives within their territories, and thereby acquire a "greater degree of civilization," was accepted by the courts as a desirable and legitimate exercise of Cherokee rights. ${ }^{12}$ However, the limited precedential value given by Canadian judges to British colonial law (as interpreted by scholars and the Marshall court) and the significant weight given to the common law of property in the early stages of Canadian Aboriginal rights jurisprudence has resulted in a much more restricted approach to the growth potential of Aboriginal practices in Canada.

The aligning of Metis interests with traditional Indian practice generates even greater difficulty for the Metis when combined with the prominent misconception that Aboriginal rights, including Metis rights, are dependant on the existence of Aboriginal title. Because of this presumption, judges instinctively draw from the principles of property law which formed part of their legal training. In the interest of legal certainty, they will also be cautious in the generation of new Metis proprietary interests. This emphasis on property has also resulted in the automatic application of controversial judicial tests established to measure the existence of Indian and Inuit title to the Metis. ${ }^{113}$ Invoking formal adherence to the doctrine of stare decisis, lower courts have

\footnotetext{
For an example of this approach see Flanagan, supra note 2. Supra note 29.

Worcester v. State of Georgia, supra note 29. See also "Metis People," supra note 5 at 368-69. See M. Asch \& C. Bell, "Definition and Interpretation of Fact in Canadian Aboriginal Title Litigation: An Analysis of Delgamuukw" (1994) 19 Queen's L.J. 503.
} 
decided Metis claims by using precedents applicable to Indian and Inuit claims with minimal modification. The Blais case, heard by Swail P.C.J. of the Manitoba Provincial Court, is a classic example of this type of reasoning. ${ }^{114}$

In Blais, four Metis were charged with unlawfully hunting deer out of season. The accused argued that they were exempt from provincial hunting laws because of their Metis status. Noting that the legal identity of Metis people is difficult to construct because of the numerous and varied uses of the term, and acknowledging the Crown's admission of the Metis identity, Swail P.C.J. proceeded on the assumption that the accused were Metis within the meaning of s. 35. Operating on the assumption that Metis Aboriginal rights to hunt cannot exist independent of Metis Aboriginal title, he applied the tests for the existence of title before addressing the central consideration identified in Sparrow: the integral nature of the hunt to the distinct culture of the accused and their ancestral Aboriginal society. The proofs of title required for Indian and Inuit peoples are:

(1) they and their ancestors were members of an organized society;

(2) the organized society occupied the specific territory over which they assert Aboriginal title;

(3) occupation was to the exclusion of other organized societies; and

(4) occupation was an established fact at the time sovereignty was asserted by England. 115

On the question of whether or not the ancestral Metis society was an organized society, Swail P.C.J. held that the Metis were organized. Although they may not have considered their practice of hunting and fishing as giving rise to Aboriginal rights, it was clear that the "Metis society of that day recognized the right of its constituent members to hunt in the lands to which the Metis had title."116 However, insufficient evidence was given to convince him that the accused and their ancestors occupied, or had a substantial connection to, the particular land over which the Metis right to hunt was asserted. Disagreement also arose over the date by which occupation of the territory must be established. The test for title requires that occupation be proved at the date sovereignty was asserted. In the context of measuring occupation of other Aboriginal peoples this date varies depending on the existence of legislative assertions, physical occupation and treaty. The Crown acknowledged that setting the date at the issuance of the Hudson's Bay Company Charter in 1670 placed too onerous a burden on the accused. Rather, the Crown maintained that the appropriate date to identify the assertion of sovereignty was 1818 , by virtue of the Convention of Commerce. At that time the "the geographical limits of British and Canadian sovereignty vis-à-vis the

IIs Baker Lake v. Min. of Indian Affairs (1980), 107 D.L.R. (3d) 513 at 542 (F.C.T.D.).

116 Blais, supra note 2 at 133. 
United States in the vicinity of the hunting site" were established. 117 The court concluded that hunting was integral to the culture of the Metis by 1818 but that this was insufficient to support a defense for the accused, who were unable to prove Aboriginal title to the area in which the offence occurred.

Adams and Côté have now put to rest the argument that Aboriginal title must be proved as a prerequisite to enjoyment of other Aboriginal rights. ${ }^{118}$ Endorsing the conclusion that "claims to title are just one manifestation of a broader based conception of Aboriginal rights," Lamer C.J.C. held that,

[s. 35] protects activities which were integral to the distinctive culture of the Aboriginal group claiming the right; [and] it does not require that that group satisfy the further hurdle of demonstrating that their connection with the piece of land on which the activity was taking place was of central significance to their distinctive culture sufficient to make out a claim to Aboriginal title to the land. ${ }^{119}$

For the Metis and other Aboriginal people, this means that they cannot be denied Aboriginal rights in a given territory because of non-exclusive use or because their social organization is deemed insufficient by the Court to support a right of occupation. Nevertheless, Aboriginal rights, such as the right to fish, may be site-specific, requiring further evidence of substantial connection to the waters over which the right is being asserted. Tests for determining the extent of Aboriginal connection for site-specific rights have not been developed. However, judges assume that the factual analysis must support the integral nature of the right to the Aboriginal people in question and a conclusion that exercising the right in the place in question was integral enough to bring that area within the scope of traditionally used lands.

An alternative approach to identifying the date that sovereignty was asserted over the Metis people of Manitoba is offered in Morin. ${ }^{120}$ Agreeing with the Crown, Meagher J. maintains that sovereignty was asserted in Rupert's Land in 1870 when Rupert's Land and the Northwest Territories were admitted into Confederation. The selection of 1870 is interesting because it raises questions addressed earlier about who is the colonizer and who is the colonized. Before the assertion of Metis Aboriginal rights, the judicial assumption had been that Aboriginal rights law was concerned with the English colonization of, and assertion of sovereignty over, Indian nations. However, in Morin the Dominion of Canada also takes on the role of the colonizer and the Metis Nation, the colonized. Not only does this approach give meaning to the recognition of the Metis Nation as an Aboriginal people distinct from Indian nations, it is also more in keeping with their historical treatment. Although British sovereignty was asserted and Rupert's Land was allegedly transferred to the Hudson's Bay Company in 1670, Aboriginal, Metis and British legal regimes co-existed until Europeans in the region increasingly demanded British justice and more western lands were needed for the expansion of the railway and British settlement. By 1870 unique Metis social institutions combined with 
European and Indian institutions to create a unique social and political identity known as the Metis Nation. In addition to Indian nations, it is this Nation against whom the new colonizer, the Dominion of Canada, went to war. It is this Nation which was represented by, and dominated, the Provisional Government that negotiated the inclusion of Manitoba into Confederation. This construction of the colonizer and colonized is crucial in understanding why the Metis maintain that another legitimate frame of reference for their claims is the law of nations. Metis government - not the government of the Hudson's Bay Company or another colonial government dominated, was in occupation and was ruling Metis people when Canada lost in its attempt to force accession of Metis territories and had to negotiate. Scholars may debate the sufficiency of this level of Metis organization to take it out from under the English Crown and into the law of nations for the resolution of their claims, but the existence of Metis government in 1870 reinforces the need to treat their issues distinctly from those of other Aboriginal governments. ${ }^{121}$ It also lends support to the argument that the Manitoba Act is a constitutional implementation of a negotiated treaty in much the same way as modern land claims subsequently implemented by legislation.

1870 is also an appropriate date to measure the existence of distinct Metis institutions because, as American law witnesses and Canadian scholars assert, the actual colonizing process through which the British Crown assumed sovereignty is more relevant in determining their rights in British law than the signing of agreements or other manifestations of English sovereignty vis-à-vis non-Aboriginal peoples. The importance of the process of colonization in understanding s. 35 rights is reflected in the dissenting opinion of L'Heureux-Dubé J. in Van der Peet when she discusses the frozen rights theory. In her eyes legal history is properly understood in terms of relationships between peoples, not the perceptions of those relationships by one people to the exclusion of another. ${ }^{122}$ Drawing support from Sparrow she advances a "dynamic" theory of rights which considers both the Aboriginal perspective of the right at stake and British colonial law regarding relationships between the Crown and the occupants of territories over which they assert jurisdiction:

First, relying on the proclamation of sovereignty by the British imperial power as the "cut-off" for the development of Aboriginal practices, traditions and customs overstates the impact of European influence on Aboriginal communities.... From the native peoples's perspective, the coming of the settlers constitutes one of many factors, though a very significant one, involved in their continuing societal change and evolution. Taking British sovereignty as the turning point in Aboriginal culture assumes that everything that the Native people did after that date was not sufficiently significant and fundamental to their culture and social organization. This is no doubt contrary to the perspective of Aboriginal people as to the significance of European arrival on their rights. ${ }^{123}$

Academic opinion varies on the characterization of the Manitoba Act as a treaty and whether the Provisional Government is properly regarded as "Metis" government rather than an ex necessite public government consisting predominantly of Metis representation. For a discussion of this issue see e.g. Dumont, supra note 3 per O'Sullivan J. dissenting; Chartrand, supra note 81 at 127; and Gibson, supra note 9 at 288.

122 Supra note 4 . Her theory draws predominately on the work of B. Slattery, supra note 22.

$123 \quad$ Supra note 4 at 234. 
Later she continues her discussion of the impact of the English doctrine of continuity:

Instead of considering it as a turning point in Aboriginal culture, British sovereignty [should] be regarded as having recognized and affirmed practices, traditions and customs which are sufficiently significant and fundamental to the culture and social organization of Aboriginal people. This idea relates to the "doctrine of continuity" founded in British imperial constitutional law, to the effect that when new territory is acquired the lex loci of organized societies, here the Aboriginal societies, continues at common law. ${ }^{124}$

Also dissenting in Van der Peet, McLachlin J. reflects on the appropriate date to measure the existence and content of the Sto:lo right to fish. She suggests that L'Heureux-Dube' J.'s approach minimizes the historic origin of the alleged right when the latter concludes that it is sufficient for a practice to have constituted an integral part of a group's culture for a substantial period of time of twenty to fifty years for it to be deserving of protection as an Aboriginal right. Identifying her own view as falling between the extremes of the majority and L'Heureux-Dubé J.'s dissent, McLachlin J. emphasizes that Aboriginal rights must be rooted in historical laws or customs of a people and that continuity must exist between the historic practice and the contemporary right asserted. However, she agrees with her colleague that the historical dimension of Aboriginal rights does not require that contemporary manifestations of traditional activities and institutions cannot be protected by s. 35 . She argues:

Aboriginal rights find their source not in a magic moment of European contact, but in the traditional laws and customs of the Aboriginal people in question.... One finds no mention in the text of s. 35(1) or in the jurisprudence of the moment of European contact as the definitive all-or-nothing time for establishing an Aboriginal right. The governing concept is simply the traditional customs and laws of people prior to the imposition of European laws and customs. What must be established is continuity between the modern practice at issue and a traditional law or custom of the Native people. Most often, that law or tradition will be traceable to time immemorial; otherwise it would not be an ancestral Aboriginal law. But date of contact is not the only moment to consider. What went before and after can be relevant too. 125

Giving examples for the application of her approach she continues:

To take another example, in parts of the west of Canada, over a century elapsed between the first contact with Europeans and imposition of "Canadian" or "European" law. During this period, many tribes lived largely unaffected by European laws and customs. I see no reason why evidence as to the laws and customs and territories of the Aboriginals in this interval should not be considered in determining the nature and scope of their Aboriginal rights. This approach accommodates the specific inclusion in s. 35(1) of the Constitution Act, 1982 of the Aboriginal rights of the Metis people, the descendants of European explorers and traders and Aboriginal women. ${ }^{126}$ 
The potential benefit of the above analysis for the Metis is lost if the majority position in Van der Peet is applied strictly to all Aboriginal peoples. In Van der Peet, the date to measure the existence of traditional Aboriginal rights is pushed back to first contact, rather than forward to actual colonization of the areas in issue. Van der Peet retreats from the generous rules of interpretation offered in Sparrow and develops new rules for the identification and definition of rights. In the Van der Peet case, Dorothy Van der Peet, a member of the Sto:lo nation, was charged with selling ten sockeye salmon for fifty dollars, contrary to fishery regulations. She alleged that the restrictions imposed by the regulations were an unjustified interference with her existing Aboriginal right to fish protected by s. 35(1). Speaking for the majority, Lamer C.J.C. set out a two-part test for the characterization and identification of Aboriginal rights. In his words "to characterize [the] claim correctly, a court should consider such factors as the nature of the action [said to have been] done pursuant to an Aboriginal right, the nature of the governmental regulation, statute or action being impugned, and the tradition, custom or practice being relied upon to establish the right."127 As discussed earlier, the second part of the test provides standards to measure if the activity claimed is properly characterized as Aboriginal. He concludes that only those practices, customs and traditions which have continuity with traditions, customs and practices that existed prior to European contact can be transformed into legally enforceable Aboriginal rights. Furthermore, in assessing the integral nature of the activity in question, he states that it must be central to Aboriginal society rather than occasional or integral, and it cannot have become integral as a result of European influence.

It is beyond the scope of this article to explore the problems in Lamer C.J.C.'s justifications for a more restrictive approach. The point is that these developments in law have made it necessary for a distinct branch of law to emerge to accommodate Metis rights. The Supreme Court has indicated that one of the purposes of $s .35$ is to address injustices of the past. However, injustices perpetrated against Metis will not be addressed if European contact is selected as a cutoff date to determine the existence of their rights because the Metis, by definition, did not exist prior to European contact. Consequently, modification of the Van der Peet criteria is necessary if Metis rights are to be realized. One potential modification is an extension backward of the Aboriginal ancestry argument. If a court is willing to base Metis rights on the fact that their Indian ancestors were in possession of land prior to European assertions of sovereignty, it should be willing to trace those origins even further back to pre-contact. However, a problem still exists because the integral test in Van der Peet focuses on what was integral to pre-contact society and continues free of European influence. Therefore this option would not be a significant enough alteration to embrace aspects of Metis culture which are neither Indian or European, but are distinctly Metis. For example, consider the application of Van der Peet to the Michif language, which emerged as a combination of English, French and Cree influences. Michif cannot be characterized as predominantly Indian in origin or free of European influence. Indeed, it is the blending of words and meanings from all three linguistic groups and cultures that makes the Michif language distinctly Metis. ${ }^{128}$

\footnotetext{
$127 \quad$ Ibid. at 203.

$128 \quad$ R.C.A.P., supra note 5 at 202,220 and $242-43$.
} 
A more complex and prevalent institution among Metis is a landholding system which is "Indian like" in its cyclical and nomadic uses but more "European" in other respects. Viewed as an institution of landholding, it is not easily characterized as either. Broken down into its component uses and territories - berry-picking, use of growth for medicinal purposes, hunting territory, collective and individual agricultural and grazing lands - it is assimilated with its European or Indian origins and an institution distinctive to the culture of the Metis is lost. Some attempts have been made by provincial governments to protect this unique method of landholding and the Metis institutions that flow from them. However, to date only Alberta has developed a comprehensive legislative scheme that protects both the collective and individual aspects of historical Metis landholding patterns. ${ }^{129}$ Although not done in the name of recognizing and protecting Metis Aboriginal rights, in substance the provincial legislation addresses two crucial components for the survival of distinct Metis culture: a secure land base and a measure of political autonomy. ${ }^{130}$

In order to avoid judicial assimilation, a court could apply the approach suggested by L'Heureux-Dubé J. Adopting a generous, large and liberal interpretation of s. 35, she argues that s. 35 must be interpreted in the context of history and culture and in a way that gives meaningful rights to contemporary Aboriginal people. In her opinion, rights should be examined from a certain level of abstraction in a way that adopts the notion of integrality as protecting distinct cultural institutions, not just specific historic practices. It is not imperative for these institutions to have existed prior to the assertion of sovereignty or pre-contact. Rather, in her opinion it is enough that they were "sufficiently significant and fundamental" to the culture and social organization of an Aboriginal people for a "substantial continuous period of time." 131 She suggests a reference of twenty to fifty years should be sufficient to measure the significance of the institution. Adopting this philosophy, if Metis land rights have not been effectively extinguished on the Metis settlements in Alberta, and the Metis in those communities have adopted a unique landholding system that has been in continuous use for twenty to fifty years, that landholding system would be an existing Aboriginal right.

A more acceptable modification of the Van der Peet test may lie somewhere between these two extremes. Principles of British colonial law and a purposive interpretation of s. 35 could support the assessment of the existence of distinct Metis institutions and peoplehood rights at the height of colonization of the particular Metis people in issue. Adopting this compromise, the key issue is "what institutions were integral to the Metis at the date of Canadian colonization" not "what Indian-like institutions existed pre-contact, before sovereignty was asserted, or at the date of colonization." In some circumstances Metis institutions may be the same as those of their Indian ancestral groups. In others, a combination of traditional Indian and European influences may have resulted in the emergence of unique Metis institutions before the actual imposition of colonial law and government. Van der Peet makes it

See C. Bell, Alberta's Metis Settlements Legislation: An Overview of Ownership and Management of Settlement Lands (Regina: Canadian Plains Research Centre, 1994).

Ibid.

Supra note 4 at 237-38. 
clear that the majority of the Supreme Court is not willing to look at the date of actual colonization as determinative in the analysis of Indian practices. However, it may be willing to make this modification for the analysis of distinctly Metis practices or institutions. The history of Metis inclusion in s. 35 may persuade the Court to give greater emphasis to the process of colonization and the peoplehood arguments of the Metis. They may also be persuaded by the fact that the division of Metis institutions into their component parts renders meaningless their constitutional identity as distinct Aboriginal peoples. If this is the case, McLachlin J.'s dissenting opinion may be the blueprint for future modifications. ${ }^{132}$

\section{Conclusion}

Unless the Supreme Court is willing to modify the Van der Peet criteria in its application to all Aboriginal peoples, the above analysis suggests that sui generis Metis rights may be a distinct category of Aboriginal constitutional rights in addition to the ancestral and equitable rights recognized by s. 35(1). Some may argue that the emergence of a new order of Metis constitutional rights violates the doctrine of stare decisis. However, this argument weakens if one considers the flexibility of the common law system and the expectation that precedent should be applied and modified in a way that enables law to change as the customs, mores and priorities in Canadian society change. Nevertheless, those who call for formal adherence to previous decisions will find the necessary and familiar distinguishing mechanisms in Van der Peet that will enable domestic law to adapt in its application to the Metis. Speaking for the majority, Lamer C.J.C. stated:

Although s. 35 includes the Metis within its definition of "aboriginal peoples of Canada," and thus seems to link their claims to those of other Aboriginal peoples under the general heading of "aboriginal rights," the history of the Metis, and the reasons underlying their inclusion in the protection given by s. 35, are quite distinct from those of other Aboriginal peoples in Canada. As such, the manner in which the Aboriginal rights of other Aboriginal peoples are defined is not necessarily determinative of the manner in which the Aboriginal rights of the Metis are defined. At the time when this Court is presented with a Metis claim under s. 35 it will then, with the benefit of the arguments of counsel, a factual context and a specific Metis claim, be able to explore the question of the purposes underlying s. 35's protection of the Aboriginal rights of Metis people, and answer the question of the kinds of claims which fall within s. 35(1)'s scope when the claimants are Metis. The fact that, for other Aboriginal peoples, the protection granted by s. 35 goes to the practices, traditions and customs of Aboriginal peoples prior to contact, is not necessarily relevant to the answer which will be given to that question. It may, or it may not, be the case that the claims of the Metis are determined on the basis of the pre-contact practices, traditions and customs of their Aboriginal ancestors; whether that is so must await determination in a case in which the issue arises. ${ }^{13}$ 